\title{
Variación espacio-temporal de larvas de peces en el golfo de Guayaquil, Ecuador
}

\section{Temporal space-variation of fish larvae in the Gulf of Guayaquil, Ecuador}

\author{
Gregoria Calderón-Peralta, $^{1,2}$, Gabriela Ayora-Macias ${ }^{1,2}$ y Pilar Solís-Coello ${ }^{1}$ \\ $\begin{array}{lll}\text { (i) } 0000-0001-9464-9246 & \text { (iD } 0000-0002-9415-323 X & \text { (iD } 0000-0002-3735-9303\end{array}$ \\ 1. Instituto Nacional de Pesca. Guayaquil, Ecuador. \\ 2.Lab.Ictioplancton.Guayaquil,Ecuador.gcalderon@institutopesca.gob.ec*,gayora@institutopesca.gob.ec,psolis@institutopesca.gob.ec \\ * Autora para correspondencia.
}

\section{RESUMEN}

$\mathrm{E}$ ste estudio presenta la densidad, composición taxonómica, distribución espacial y temporal de larvas de peces en el golfo de Guayaquil, así como la relación con algunas variables físico-químicas. Se recolectaron muestras en 16 estaciones, tomadas en la primera milla náutica del estuario externo e interior del golfo, ubicadas frente a la provincia de Guayas y noroeste de la isla Puná, durante junio a diciembre de 2012. Se realizaron arrastres superficiales con una red cónica simple (ojo de malla: $300 \mu \mathrm{m}$; diámetro de boca: $0,3 \mathrm{~m}$; largo: 1,2 m). La temperatura, salinidad y transparencia fueron medidas antes de cada arrastre. Se detectaron diferencias significativas entre zonas, registrando mayor temperatura, menor salinidad y transparencia en el estuario interior. Se colectaron $321638 \mathrm{ind} / 100 \mathrm{~m}^{3} \mathrm{de}$ larvas de peces, pertenecientes a 13 familias y 36 especies entre la zona externa e interna. Engraulidae (58,9\%) fue la familia más abundante en las estaciones del estuario exterior, seguida de Sciaenidae (22,8\%) y Haemulidae $(9,6 \%)$. Las familias más frecuentes en el estuario interior fueron Engraulidae (74,4 \%) y Gobiidae (16,1\%). El $85 \%$ de la densidad total fue aportada por cinco especies, de las cuales Anchoa sp. y Bairdiella sp. fueron las más abundantes y dominantes, principalmente durante diciembre. La estructura y composición de la comunidad larvaria fue significativamente diferentes entre áreas ( $M W-U=450 ; \mathrm{p}<0,05)$ y meses de muestreo $(\mathrm{KW}=14,24 ; \mathrm{p}<0,05)$, con mayores registros en el estuario exterior durante diciembre. Con el análisis de redundancia (ADR) se observa que, en el área externa, las especies estuvieron asociadas con la transparencia del agua, mientras que las especies que concurrieron en la zona interna se relacionaron positivamente con la salinidad. En términos generales, la abundancia y riqueza de larvas de peces en el área externa del golfo de Guayaquil está relacionada con las condiciones de transparencia y salinidad local, las cuales favorecieron a la presencia larval.

PALABRAS CLAVE: ictioplancton, golfo de Guayaquil, variables hidrográficas, estuario, Ecuador.

\section{ABSTRACT}

$\mathrm{T}$

This study presents the density, taxonomic composition, spatial and temporal distribution of fish larvae in the Gulf of Guayaquil, as well as the relationship with some physical-chemical variables. Samples were collected at 16 stations, taken in the first nautical mile of the external and internal estuary of the gulf, located in front of the province of Guayas and northwest of the island of Puná, during June to December 2012. Surface trawls were carried out with a simple conical network (mesh eye: $300 \mu \mathrm{m}$; mouth diameter: $0.3 \mathrm{~m}$; length: $1.2 \mathrm{~m}$ ). Temperature, salinity, and transparency were measured before each drag. Significant differences were detected between zones, registering higher temperatures, lower salinity, and transparency in the interior estuary. $321638 \mathrm{ind} / 100 \mathrm{~m}^{3}$ of fish larvae were collected, belonging to 13 families and 36 species between the external and internal zone. Engraulidae (58.9\%) was the most abundant family in the exterior estuary stations, followed by Sciaenidae (22.8 \%) and Haemulidae (9.6 \%). Most frequent families in the interior estuary were Engraulidae $(74.4 \%)$ and Gobiidae (16.1\%). $85 \%$ of the total density was contributed by five species, of which Anchoa sp. and Bairdiella sp. were the most abundant and dominant, mainly during December. Structure and composition of the larval community were significantly different between areas (MW-U $=450 ; \mathrm{p}<0.05)$ and months of sampling $(\mathrm{KW}=14.24 ; \mathrm{p}<0.05)$, with higher records in the exterior estuary during December. With the redundancy analysis (ADR) it is observed that in the exterior area, the species were associated with the transparency of the water, while the species that concurred in the interior zone were positively related to salinity. In general terms, the abundance and richness of fish larvae in the external area of the Gulf of Guayaquil is related to the conditions of transparency and local salinity, which favored the larval presence.

KEYWORDS: ichthyoplankton, gulf of Guayaquil, hydrographic variables, estuary, Ecuador. 


\section{INTRODUCCIÓN}

El golfo de Guayaquil constituye el rasgo geomorfológico más singular de todo el perfil de la costa ecuatoriana. Se trata de una región oceánica y otra costera dividida en dos grandes sistemas estuarinos con propiedades fisiográficas, geológicas y oceanográficas, características representadas por su alta productividad, baja diversidad y un pronunciado estrés ambiental, dominado por impredecibles fluctuaciones de salinidad (Comisión Asesora Ambiental [CAAM], 1995).

Los estuarios juegan un rol destacado en el ciclo vital de muchas poblaciones marinas (Ketchum, 1992). Son identificados como sitios importantes de crianza, dada la disponibilidad apropiada de áreas para refugio y/o alimentación, lo cual genera condiciones favorables para el asentamiento de larvas y juveniles de diferentes organismos acuáticos de valor económico (Barletta et al., 1998, 2003; Able et al., 1999) como crustáceos, moluscos y peces. Estos últimos están considerados como uno de los grupos más importantes, puesto que desempeñan roles ecosistémicos significativos tales como transformación del potencial energético del detritus, transferencia de energía entre diferentes niveles de las redes tróficas y balance de energía entre ecosistemas vecinos (Yánez-Arancibia y Nugent, 1977; Beck et al., 2001).

Las comunidades de peces estuarinos representan una combinación de especies de agua dulce y marina, que viven en el límite de su distribución, residentes estuarinos y especies migratorias que atraviesan el estuario con fines reproductivos o tróficos (Maes et al., 1998). La distribución de sus etapas planctónicas está determinada en conjunto por diversos factores fisicoquímicos, ciclo de mareas y corrientes, dado que las larvas al permanecer suspendidas en la columna de agua están en mayor grado relacionadas a los movimientos de los ciclos mareales. De igual modo, están sujetas a los ciclos anuales de maduración de los adultos conjuntamente con sus estrategias reproductivas, ya que más del $80 \%$ de los peces litorales utilizan el estuario en alguna de sus etapas de madurez y/o desarrollo (Yáñez-Arancibia y Nugent, 1977). La gran mayoría entran al estuario como larvas, desde ambientes marinos adyacentes; otros peces desovan dentro del estuario hasta completar su ciclo de vida y lo abandonan siendo juveniles (Whitfield, 1999). Por ende, la composición del ictioplancton de un estuario es fluctuante a lo largo del tiempo y existe poca relación con la composición de adultos cuando se trata de especies

\section{INTRODUCTION}

The Gulf of Guayaquil constitutes the most singular geomorphological feature of the entire profile of the Ecuadorian coast. It is an oceanic and a coastal region divided into two large estuarine systems with physiographic, geological and oceanographic properties, characteristics represented by its high productivity, low diversity and pronounced environmental stress, dominated by unpredictable fluctuations in salinity (Comisión Asesora Ambiental [CAAM], 1995).

Estuaries play a prominent role in the life cycle of many marine populations (Ketchum, 1992). They are identified as important breeding sites, given the appropriate availability of areas for shelter and/or feeding, which generates favorable conditions for the settlement of larvae and juveniles of different aquatic organisms of economic value (Barletta et al., 1998, 2003; Able et al., 1999) such as crustaceans, mollusks, and fish. The latter is considered one of the most important groups since they play significant ecosystem roles such as the transformation of the debris energy potential, energy transfer between different levels of the trophic networks and energy balance between neighboring ecosystems (Yánez-Arancibia and Nugent, 1977; Beck et al., 2001).

Estuarine fish communities represent a combination of freshwater and marine species, living on the edge of their distribution, estuarine residents, and migratory species that traverse the estuary for reproductive or trophic purposes (Maes et al., 1998). The distribution of their planktonic stages is determined jointly by various physicochemical factors, tidal cycle and currents, since the larvae when suspended in the water column are to a greater degree related to the movements of the tidal cycles. Likewise, they are subject to the annual maturation cycles of adults together with their reproductive strategies, since more than $80 \%$ of the coastal fish use the estuary in one of its stages of maturity and/or development (Yáñez-Arancibia and Nugent, 1977). The vast majority enters the estuary as larvae, from adjacent marine environments; other fish spawn within the estuary to complete their life cycle and leave it as juveniles (Whitfield, 1999). Therefore, the composition of the ichthyoplankton in an estuary fluctuates over time, with little relation to the composition of adults when it comes to non-resident species. Given this, knowledge of the temporal and spatial distribution of ichthyoplankton is essential, not only for understanding adult population fluctuations and 
no residentes. Dado esto, el conocimiento de la distribución temporal y espacial del ictioplancton es fundamental, no solo para el entendimiento de las fluctuaciones poblacionales de los adultos y sus áreas potenciales de desove, sino también para comprender el funcionamiento general del ecosistema estuarino (Moser y Smith, 1993a; Cowan y Shaw, 2002; Ottersen et al., 2010) y la recurrencia de las especies en este sistema.

En Ecuador, se han desarrollado variadas investigaciones taxonómicas de larvas de peces marinos, pudiendo establecer su distribución y abundancia. Los trabajos de Cajas e Hinostroza (1981), Peribonio et al. (1981), García (1983), Ortega et al. (1996), Luzuriaga de Cruz et al. (1998), Torres et al. (2003-2004) y Calderón et al. (2018) enfatizan al golfo de Guayaquil como un área productiva, siendo particularmente al sur de la isla Puná donde se presenta la mayor dominancia de huevos y larvas de peces primordialmente de interés comercial, y que se extiende al norte del golfo hacia la costa y al sur del océano, donde según Jiménez y Bonilla (1980) existe una relación entre el patrón de distribución del fitoplancton con el del ictioplancton. Recientemente, Salcedo y Coello (2018), en su trabajo sobre la dinámica del plancton frente a la provincia de El Oro, reportan la dominancia de larvas de peces de la familia Engraulidae con dos períodos de abundancia, de junio a agosto y de octubre a diciembre, resultado de las concentraciones de Anchovia macrolepidota, la especie característica de este ecosistema. El presente trabajo de investigación determinó los patrones de densidad y distribución (espacial y temporal) de larvas de peces en el estuario interior y exterior adyacente del golfo de Guayaquil, evaluando su relación con las condiciones locales de temperatura, salinidad y transparencia, durante junio a diciembre de 2012, meses que caracterizan a la época seca y de transición en el Ecuador.

\section{MATERIALES Y MÉTODOS}

Área de estudio

La provincia del Guayas está ubicada al suroeste de Ecuador y recibe la influencia de varias corrientes marinas, especialmente la fría de Humboldt durante la época seca, de julio a noviembre, y la cálida de El Niño en la época lluviosa, de enero a mayo, mientras que junio y diciembre son considerados meses de transición (Twilley et al., 2001; Prado et al., 2015), los cuales producen un clima de tipo tropical sabana y tropical monzón con temperaturas promedio de $25^{\circ} \mathrm{C}$ y precipitaciones anuales entre 500 a $1000 \mathrm{~mm}$ (Twilley et al., their potential spawning areas but also for understanding the general functioning of the estuarine ecosystem (Moser and Smith, 1993a; Cowan and Shaw, 2002; Ottersen et al., 2010) and the recurrence of species in this system.

In Ecuador, various taxonomic investigations of marine fish larvae have been carried out, establishing their distribution and abundance. The works by Cajas and Hinostroza (1981), Peribonio et al. (1981), García (1983), Ortega et al. (1996), Luzuriaga de Cruz et al. (1998), Torres et al. (2003-2004) and Calderón et al. (2018) emphasize the Gulf of Guayaquil as a productive area, being particular to the south of the Puná Island where the increased dominance of fish eggs and larvae primarily of commercial interest, and that it extends to the north of the gulf towards the coast and to the south of the ocean, where according to Jiménez and Bonilla (1980) there is a relationship between the distribution pattern of phytoplankton with that of ichthyoplankton. Recently, Salcedo and Coello (2018), in their work on the dynamics of plankton against the province of El Oro, report the dominance of fish larvae of the family Engraulidae with two periods of abundance, from June to August and from October to December, a result of the concentrations of Anchovia macrolepidota, the characteristic species of this ecosystem. This research work determined the density and distribution patterns (spatial and temporal) of fish larvae in the adjacent interior and exterior estuary of the Gulf of Guayaquil, evaluating their relationship with local conditions of temperature, salinity, and transparency, during June to December 2012, months that characterize the dry and transitional season in Ecuador.

\section{MATERIALS AND METHODS}

Study area

The Guayas province is located in the southwest of Ecuador and is influenced by several marine currents, especially the cold of Humboldt during the dry season, from July to November, and the warm El Niño in the rainy season, from January to May; while June and December are considered transitional months (Twilley et al., 2001; Prado et al., 2015), which produce a tropical savanna and tropical monsoon type climate with average temperatures of $25{ }^{\circ} \mathrm{C}$ and annual rainfall between 500 to $1000 \mathrm{~mm}$ (Twilley et al., 2001). In the coastal margin of this province, the Gulf of Guayaquil $\left(3^{\circ} \mathrm{S} .80^{\circ} \mathrm{W}\right)$, the Southeast Pacific main estuary, is located, which is divided into two specific areas: a so-called exterior estuary, an open oceanic region 
2001). En el margen costero de esta provincia, está ubicado el golfo de Guayaquil $\left(3^{\circ} \mathrm{S} .80^{\circ} \mathrm{W}\right)$, principal estuario del Pacífico sudeste, el cual se divide en dos áreas específicas: una denominada estuario exterior, región oceánica abierta influenciada por las masas de aguas del pacífico tropical, que se inicia a la altura de la puntilla de Santa Elena y posee como límite la plataforma a lo largo del meridiano $81^{\circ} \mathrm{W}$ hasta el lado occidental de la isla Puná $\left(80^{\circ} 15^{\prime} \mathrm{W}\right)$, con predominio de cordones litorales y acantilados altos e inestables (Ayón, 1987). Por otra parte, el estuario interior, conocido como el estuario del río Guayas, se encuentra conformado al noroeste por el estero Salado y al sureste por el estero Churute, que recibe los aportes de los ríos Taura y Churute (Cucalón, 1996), regido principalmente por las mareas, la descarga fluvial y el esfuerzo del viento, con abundancia de manglar que le da un aspecto de un gran pantano (CAAM, 1995). En términos generales, la profundidad del golfo de Guayaquil en la plataforma continental va desde $180 \mathrm{~m}$ en el borde occidental hasta menos de $20 \mathrm{~m}$ en la parte interior (Montaño-Armijos y Sanfeliu-Montolio, 2008).

\section{Muestreo}

El material proviene de 112 muestras de zooplancton recolectadas en 16 estaciones de muestreo, ubicadas a $1 \mathrm{mn}$ $(1,8 \mathrm{~km})$ de distancia del margen costero frente a la provincia del Guayas y el noroeste de la isla Puná, durante el período de época seca (julio a noviembre) y transición (junio y diciembre) de 2012. Las estaciones fueron seleccionadas por su importancia como áreas de actividad reproductiva de peces y categorizadas en función de su ubicación: la zona interna o estuario interior, representada por ocho $(8,9,10,11,12,13,14$ y 15) estaciones someras y cercanas a la influencia de estuarios y ríos, y la zona externa o estuario exterior por ocho $(1,2,3,4,5,6,7$ y 16$)$ estaciones con mayor influencia marina (Figura 1).

En cada estación se efectuaron registros verticales de temperatura y salinidad con un perfilador de CTD marca Sea-Bird, modelo Seacat S19V2, y la transparencia del agua se determinó con un disco Secchi (m). Las muestras de zooplancton fueron colectadas durante marea alta mediante arrastres superficiales (0-1 $\mathrm{m}$ de profundidad), diurnos (entre las 08:00 y 11:00 horas), circulares, con una duración de $5 \mathrm{~min}$ y a una velocidad de $3,7 \mathrm{~km} / \mathrm{h}$ a bordo de una embarcación con motor fuera de borda. Se utilizó una red cónica simple de $30 \mathrm{~cm}$ de diámetro, $1,2 \mathrm{~m}$ de longitud y $300 \mu \mathrm{m}$ de abertura de malla. En la boca de la red se adosó un flujómetro General Electric ${ }^{\circledR}$ para cuantificar el volumen de agua filtrada y estandarizar la abundancia por unidad de volumen. Las influenced by the masses of tropical Pacific waters, which begins at the height of the point of Santa Elena and has as its limit at the platform along the meridian $81^{\circ} \mathrm{W}$ to the western side of the Puná island $\left(80^{\circ} 15^{\prime} \mathrm{W}\right)$, with a predominance of coastal cords and high and unstable cliffs (Ayón, 1987). On the other hand, the interior estuary, known as the Guayas River estuary, is made up to the northwest by the Salado estuary and to the southeast by the Churute estuary, which receive the contributions of the Taura and Churute rivers (Cucalón, 1996), governed mainly by the tides, the river discharge and the effort of the wind, with an abundance of mangroves that give it the appearance of a large swamp (CAAM, 1995). In general terms, the depth of the Gulf of Guayaquil on the continental shelf ranges from $180 \mathrm{~m}$ at the western edge to less than $20 \mathrm{~m}$ in the interior (MontañoArmijos and Sanfeliu-Montolio, 2008).

Sampling

The material comes from 112 samples of zooplankton collected in 16 sampling stations, located $1 \mathrm{mn}$ $(1.8 \mathrm{~km})$ away from the coastal margin in front of the province of Guayas and northwest of the island of Puná, during the dry season period (July to November) and transition (June and December) 2012. The stations were selected for their importance as areas of fish reproductive activity and categorized according to their location: the interior zone or inland estuary, represented by eight $(8.9,10,11,12,13,14$ and 15$)$ shallow and close stations influenced by estuaries and rivers, and the exterior zone or exterior estuary by eight $(1,2,3,4,5,6,7$ and 16$)$ stations with greater marine influence (Figure 1).

Vertical records of temperature and salinity were made in each station with a Sea-Bird brand CTD profiler, Seacat S19V2 model, and the transparency of the water was determined with a Secchi (m) disk. The zooplankton samples were collected at high tide using surface trawls (0-1 m deep), daytime (between 08:00 and 11:00 am), circular, with a duration of $5 \mathrm{~min}$ and at a speed of $3.7 \mathrm{~km} / \mathrm{h}$ on board a boat with an outboard motor. A simple conical network $30 \mathrm{~cm}$ in diameter, $1.2 \mathrm{~m}$ in length, and $300 \mu \mathrm{m}$ of mesh opening was used. At the mouth of the network, a General Electric ${ }^{\circledR}$ flowmeter was attached to quantify the volume of filtered water and standardize the abundance per unit volume. The zooplankton samples were fixed in a formalin solution with seawater at a final concentration of $4 \%$ and transported to the Ichthyoplankton Laboratory of the National Fisheries Institute (Guayaquil, Ecuador). 


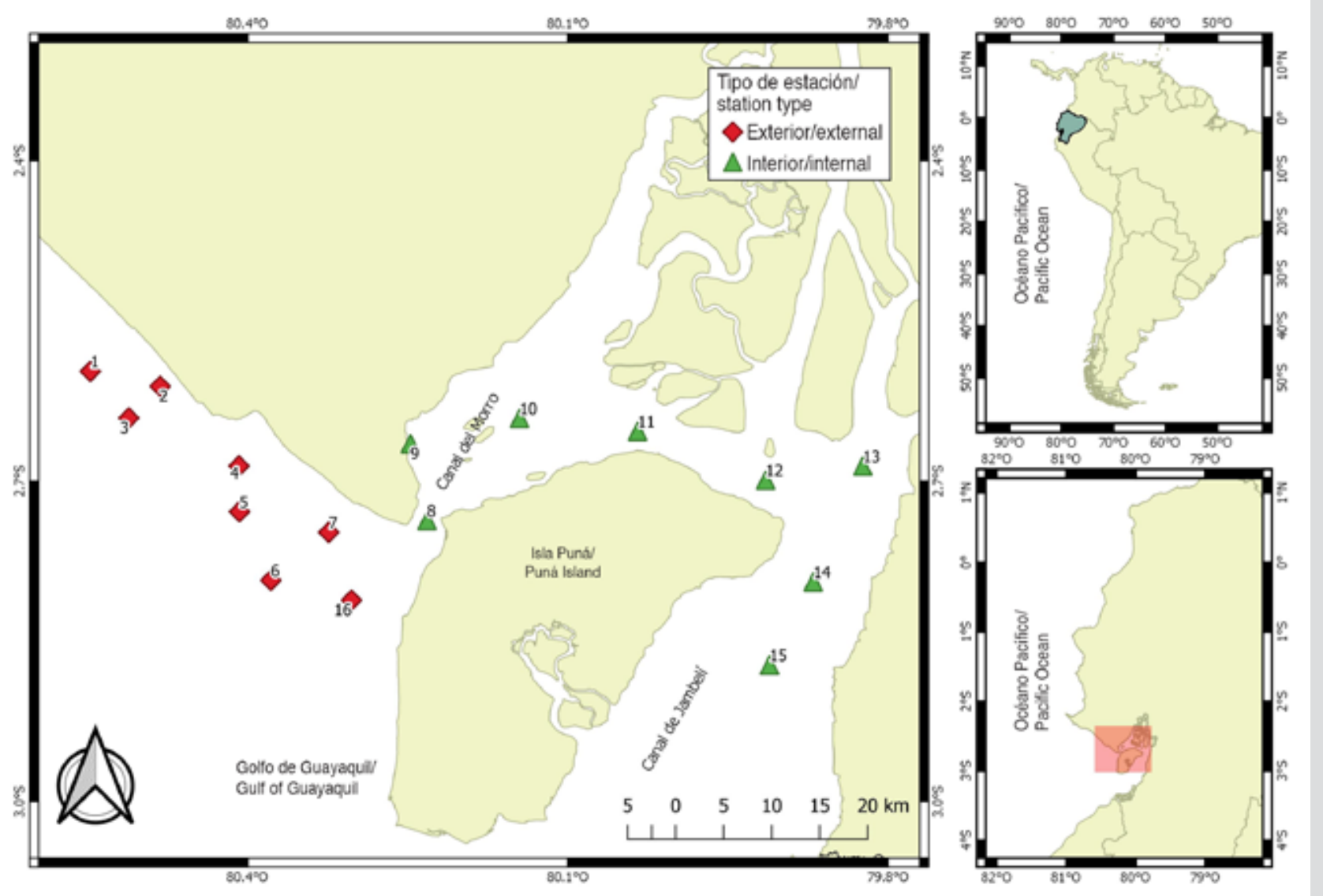

Figura 1. Ubicación geográfica de las estaciones de muestreo en la provincia de Guayas
Figure 1. Geographical location of the sampling stations in the province of Guayas. muestras de zooplancton fueron fijadas en una solución de formalina con agua de mar a una concentración final de $4 \%$ y se transportaron al Laboratorio de Ictioplancton del Instituto Nacional de Pesca (Guayaquil, Ecuador).

Análisis de laboratorio

Se revisó la totalidad de cada una de las muestras. Se separaron, contaron y estandarizaron a número de individuos $/ 100 \mathrm{~m}^{3}$ de superficie marina, a partir del método descrito por Smith y Richardson (1979). Las larvas fueron identificadas hasta el menor nivel taxonómico posible, siguiendo los criterios establecidos en Moser (1996), BeltránLeón y Ríos (2000-2001), Richards (2005) y Calderón (2011).

\section{Análisis de datos}

Se evaluaron las diferencias de la variabilidad hidrográfica y la abundancia de larvas de peces, considerando como factor de variabilidad en el espacio las zonas de estudio (interna y externa) y utilizando la prueba paramétrica de Mann Whitney (MW-U) (Sheskin, 2004) mediante el programa Statgraphics Plus 5,1.

\section{Laboratory analysis}

All of the samples were reviewed. The number of individuals $/ 100 \mathrm{~m}^{3}$ of sea surface was separated, counted, and standardized, using the method described by Smith and Richardson (1979). Larvae were identified down to the lowest possible taxonomic level, following the criteria established in Moser (1996), Beltrán-León and Ríos (20002001), Richards (2005) and Calderón (2011).

\section{Analysis of data}

Differences in hydrographic variability and abundance of fish larvae were evaluated, considering the study areas (internal and external) as a factor of variability in space, and using the Mann Whitney parametric test (MW-U) (Sheskin, 2004) through the Statgraphics Plus 5.1 program.

With the quantitative data, the relative abundance of the families and species of fish larvae by months and study areas was calculated. The estimation of the specific richness (S), diversity (H') and equity (J') of the larval 
Con los datos cuantitativos se procedió al cálculo de la abundancia relativa de las familias y especies de larvas de peces por meses y zonas de estudio. La estimación de la riqueza especifica (S), diversidad (H') y equidad (J') de la comunidad larvaria se describió mediante los índices de atributos comunitarios de Shannon-Weaver (Shanon y Weaver, 1963) y Pielou utilizando el logaritmo base 2 (Tsirstsis y Karydis, 1998; Krebs, 1999) con una unidad de bits/Ind y desarrollado con el software estadístico de libre acceso Past 3,0. Además, se utilizó el método de interpolación "inverso a la distancia" con el programa computacional QGIS ${ }^{\circledast} 3,0$ para representar la variación espacial de la abundancia de larvas de peces y las condiciones oceanográficas en el área para la época de estudio.

Para establecer posibles diferencias en la estructura comunitaria de larvas de peces entre zonas, se utilizó el análisis multidimensional no paramétrico (MDS-Anosim), y para determinar el aporte de las especies entre zonas, se obtuvo el porcentaje de similaridad Simper. Todos los análisis multivariados se realizaron mediante el software Past 3,0 (Hammer et al., 2001). Por último, se evaluó el grado de relación entre la estructura establecida del ensamblaje de larvas de peces y las condiciones físico-químicas por cada zona de estudio utilizando un análisis de redundancia (RDA) desarrollado con el software estadístico de libre acceso PcOrd 6,0 (McCune y Grace, 2002). Esta prueba de asociación multivariada maximiza el grado de correlación entre la abundancia de larvas peces y los parámetros físico-químicos.

\section{RESULTADOS}

\section{Condiciones ambientales}

La variabilidad de la temperatura superficial del mar (TSM) permitió identificar diferencias significativas (MW-U: 2632; $p<0,05$ ) entre las zonas de estudio (Figura 2; Tabla 1) y los mayores registros promedios en el estuario interior $\left(25,7^{\circ} \mathrm{C}\right)$, principalmente en las estaciones cercanas al canal del Morro (estación nueve, 10 y 11) (Figura 3a). La variación temporal de la TSM mostró un promedio de $25,2^{\circ} \mathrm{C}$ $( \pm 0,71)$ con el valor mínimo $\left(24,3^{\circ} \mathrm{C}\right)$ en agosto y el máximo $\left(26,5{ }^{\circ} \mathrm{C}\right)$ en junio. En conjunto, los meses de la época de transición (junio y diciembre) registraron los valores más altos de temperatura superficial del mar $\left(26,1-25,5{ }^{\circ} \mathrm{C}\right)$ (Figura 2a y Figura 2b).

La salinidad presentó diferencias significativas (Figura 2; Tabla 1) entre zonas de muestreo (MW-U: 89; $p<0,05)$, con los menores registros en el estuario interior, principalmente en las estaciones ocho y diez. En el estuario community was described utilizing the community attribute indices of Shannon-Weaver (Shanon and Weaver, 1963) and Pielou using the base logarithm 2 (Tsirstsis and Karydis, 1998; Krebs, 1999) with a bit/Ind unit and developed with the open-access statistical software Past 3.0. Also, the "inverse to distance" interpolation method was used with the QGIS $^{\circledR} 3.0$ computer program to represent the spatial variation of the abundance of fish larvae and the oceanographic conditions in the area for the study period.

To establish possible differences in the community structure of fish larvae between zones, nonparametric multidimensional analysis (MDS-Anosim) was used and to determine the contribution of the species between zones, the SIMPER percentage of similarity was obtained. All multivariate analyzes were performed using the Past 3.0 software (Hammer et al., 2001). Finally, the degree of relationship between the established structure of the fish larvae assembly and the physical-chemical conditions for each study area was evaluated, using redundancy analysis (RDA) developed with the free access statistical software PcOrd 6.0 (McCune and Grace, 2002). This multivariate association test maximizes the degree of correlation between the abundance of fish larvae and the physicalchemical parameters.

\section{RESULTS}

\section{Environmental conditions}

The variability of the sea surface temperature (SST) allowed identifying significant differences (MW-U: 2632; $<$ 0.05) between the study areas (Figure 2; Table 1) and the highest average records in the interior estuary $\left(25.7^{\circ} \mathrm{C}\right)$, mainly in the stations near the Morro canal (station nine, 10 and 11) (Figure 3a). The temporal variation of the SST showed an average of $25.2{ }^{\circ} \mathrm{C}$ $( \pm 0.71)$ with the minimum value $\left(24.3^{\circ} \mathrm{C}\right.$ ) in August and the maximum $\left(26.5^{\circ} \mathrm{C}\right)$ in June. Overall, the months of the transition period (June and December) recorded the highest values of sea surface temperature $\left(26.1-25.5{ }^{\circ} \mathrm{C}\right)$ (Figure 2a and Figure 2b).

Salinity presented significant differences (Figure 2; Table 1) between sampling areas (MW-U: 89; $\mathrm{p}<0.05$ ), with the lowest records in the interior estuary, mainly in stations eight and ten. In the exterior estuary, the highest salinity values were recorded in stations two and three, located near the coast of Santa Elena and with the greatest 
exterior, los máximos valores de salinidad se registraron en las estaciones dos y tres, ubicadas cerca de la costa de Santa Elena y con mayor aporte marino (Figura 3b). La salinidad promedio de junio a diciembre fue de $31,4( \pm 0,7)$ con rangos de 30,7 a 32,2 ups, con el mínimo en junio, julio y agosto, y el máximo en noviembre (Figura 2c y Figura 2d). marine contribution (Figure $3 b$ ). The average salinity from June to December was $31.4( \pm 0.7)$ with ranges from 30.7 to 32.2 ups, with the minimum in June, July, and August, and the maximum in November (Figure 2c and Figure 2d).
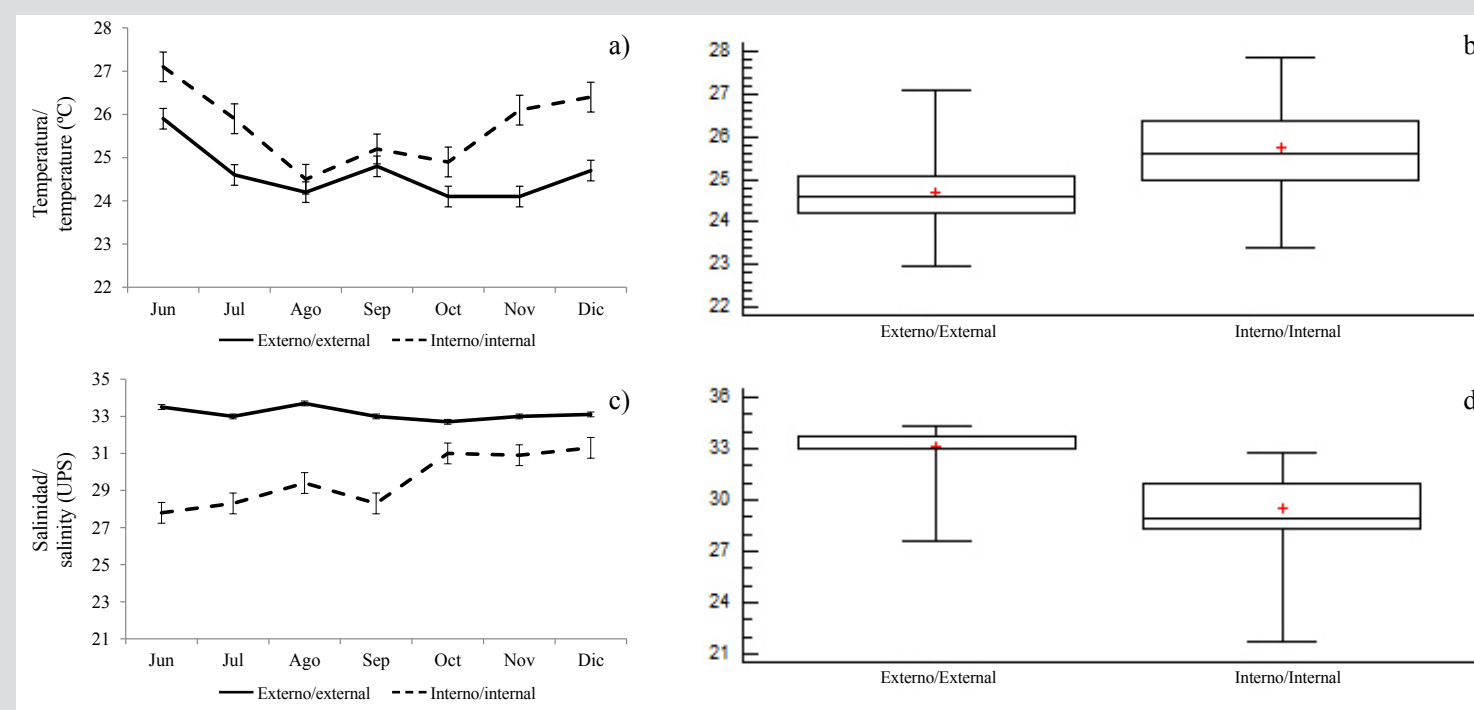

b)
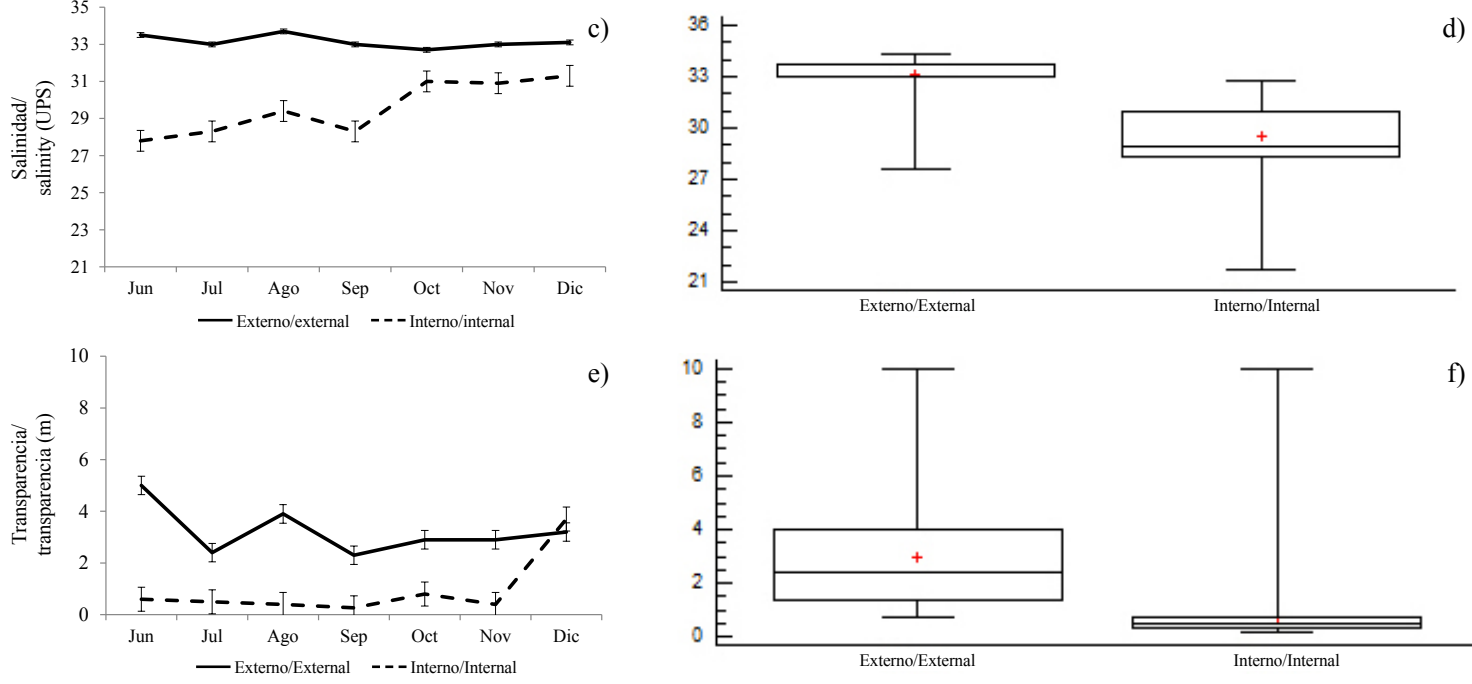

e)

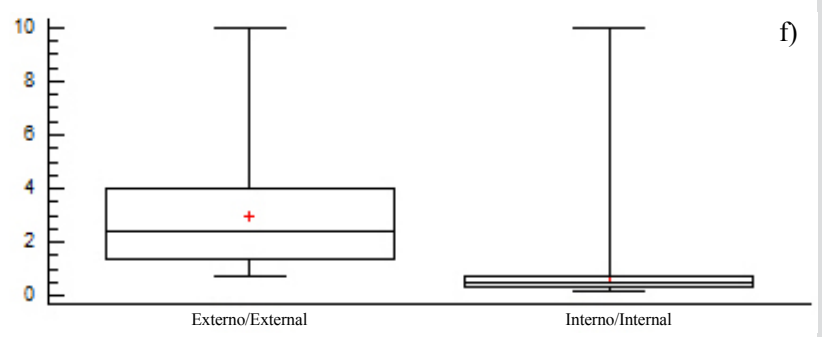

Figura 2. Variación mensual y por zonas: a y b) temperatura, c y d) salinidad, e y f) transparencia, en el estuario exterior e interior del golfo de Guayaquil frente a la provincia del Guayas entre junio y diciembre de 2012. La línea horizontal corresponde a la mediana y el punto al promedio.
Figure 2. Monthly variation and by zones: a and b) temperature, $c$ and d) salinity, e and f) transparency, in the exterior and interior estuary of the Gulf of Guayaquil against the province of Guayas between June and December 2012. The horizontal line corresponds to the median and the point to the average.
La transparencia del agua mostró un promedio de 2,0 $\mathrm{m}( \pm 2,4)$, con diferencias significativas (Figura 2, Tabla 1) entre zonas (MW-U: 120; $\mathrm{p}<0,05$ ), con los menores registros en el estuario interior, principalmente en las estaciones ubicadas en la boca del canal del Morro $(8,9,10)$ y el canal Cascajal (11 y 12) (Figura 3c). En los meses estudiados, la transparencia mostró el menor registro $(1,3 \mathrm{~m})$ en julio y el máximo (2,6 m) en junio (Figura $2 \mathrm{~g}$ y Figura $2 \mathrm{~h}$ ). En general, se observó la zona externa con menor temperatura, pero con mayor salinidad y transparencia con respecto a la zona interna del golfo de Guayaquil (Figura 3, Tabla 1).
The transparency of the water showed an average of $2.0 \mathrm{~m}( \pm 2.4)$, with significant differences (Figure 2, Table 1) between zones (MW-U: 120; p < 0.05), with the lowest records in the interior estuary, mainly in the stations located at the mouth of the Morro channel $(8,9$, 10) and the Cascajal channel (11 and 12) (Figure 3c). In the months studied, transparency showed the lowest record $(1.3 \mathrm{~m})$ in July and the highest $(2.6 \mathrm{~m})$ in June (Figure $2 \mathrm{~g}$ and Figure $2 \mathrm{~h}$ ). In general, the external zone was observed with a lower temperature, but with greater salinity and transparency to the internal zone of the Gulf of Guayaquil (Figure 3, Table 1). 


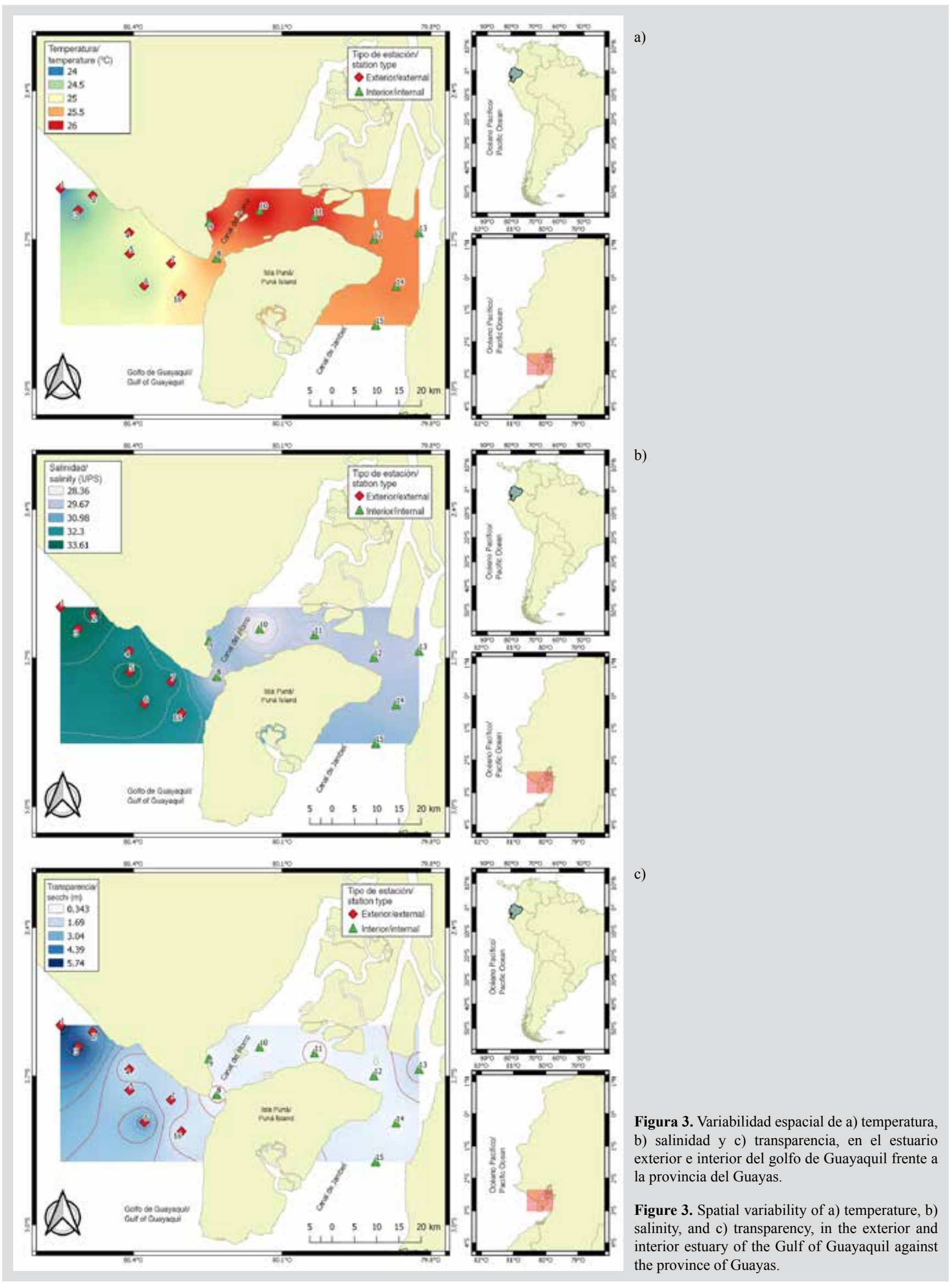


Tabla 1. Parámetros físico-químicos registrados en el estuario exterior e interior del golfo de Guayaquil frente a la provincia del Guayas entre junio y diciembre de 2012. $\mu$ : promedio, D.s.: desviación estándar, Min: valor mínimo registrado. Max: valor máximo registrado. W: valor de Wilcoxon, p: valor de probabilidad.
Table 1. Physical-chemical parameters recorded in the exterior and interior estuary of the Gulf of Guayaquil against the province of Guayas between June and December 2012. $\mu$ : average, D.s.: standard deviation, Min: minimum recorded value. Max: maximum registered value. W: Wilcoxon value, p: probability value.

\begin{tabular}{|c|c|c|c|c|c|c|c|c|c|c|}
\hline & \multicolumn{4}{|c|}{ Estuario exterior/Exterior estuary } & \multicolumn{4}{|c|}{ Estuario interior/Interior estuary } & \multirow{2}{*}{$\mathbf{W}$} & \multirow{2}{*}{$\mathbf{P}$} \\
\hline & $\mu$ & D.s. & Min & Max & $\mu$ & D.s. & Min & Max & & \\
\hline Temperatura/Temperature $\left({ }^{\circ} \mathrm{C}\right)$ & 24.67 & 0.10 & 24.10 & 25.16 & 25.75 & 0.12 & 25.52 & 26.06 & 2632 & $<0.05$ \\
\hline Salinidad/Salinity (UPS) & 33.08 & 0.12 & 32.49 & 33.57 & 29.57 & 0.25 & 28.35 & 30.41 & 89 & $<0.05$ \\
\hline Transparencia/Transparency (m) & 2.98 & 0.27 & 1.11 & 5.75 & 0.69 & 0.19 & 0.34 & 1.7 & 492 & $<0.05$ \\
\hline
\end{tabular}

\section{Estructura comunitaria de larvas de peces}

Se cuantificaron un total de 321638 larvas $/ 100 \mathrm{~m}^{3}$, con diferencias significativas entre las zonas de muestreo (MW-U: 450; $\mathrm{p}<0,05$ ) (Figura 4). La distribución espacial mostró mayores densidades larvales promedio hacia el estuario exterior (8458 larvas $/ 100 \mathrm{~m}^{3}, \pm 25215$ ), con máximos (122 648 larvas $/ 100 \mathrm{~m}^{3}$ ) en la estación siete y mínimos (16 376 larvas $/ 100 \mathrm{~m}^{3}$ ) en la estación cinco. El estuario interior, con un promedio de 2272 larvas/100 $\mathrm{m}^{3}$ ( \pm 4 967), registró la máxima densidad en la estación ocho, ubicada en la bocana del canal del Morro, con 8676 larvas $/ 100 \mathrm{~m}^{3}$ y menor densidad en la estación nueve con 906 larvas $/ 100 \mathrm{~m}^{3}$ (Figura 4).

\section{Community structure of fish larvae}

A total of 321,638 larvae $/ 100 \mathrm{~m}^{3}$ were quantified, with significant differences between the sampling areas (MW-U: 450; $<$ 0.05) (Figure 4). The spatial distribution showed higher average larval densities towards the exterior estuary $\left(8,458\right.$ larvae $\left./ 100 \mathrm{~m}^{3}, \pm 25,215\right)$, with maximums $\left(122,648\right.$ larvae $\left./ 100 \mathrm{~m}^{3}\right)$ in station seven and minimums $\left(16,376\right.$ larvae $\left./ 100 \mathrm{~m}^{3}\right)$ in station five. The interior estuary, with an average of 2,272 larvae $/ 100 \mathrm{~m}^{3}( \pm 4,967)$, registered the highest density in station eight, located at the mouth of the Canal del Morro, with 8,676 larvae $/ 100 \mathrm{~m}^{3}$ and lower density in station nine with 906 larvae/100 $\mathrm{m}^{3}$ (Figure 4).

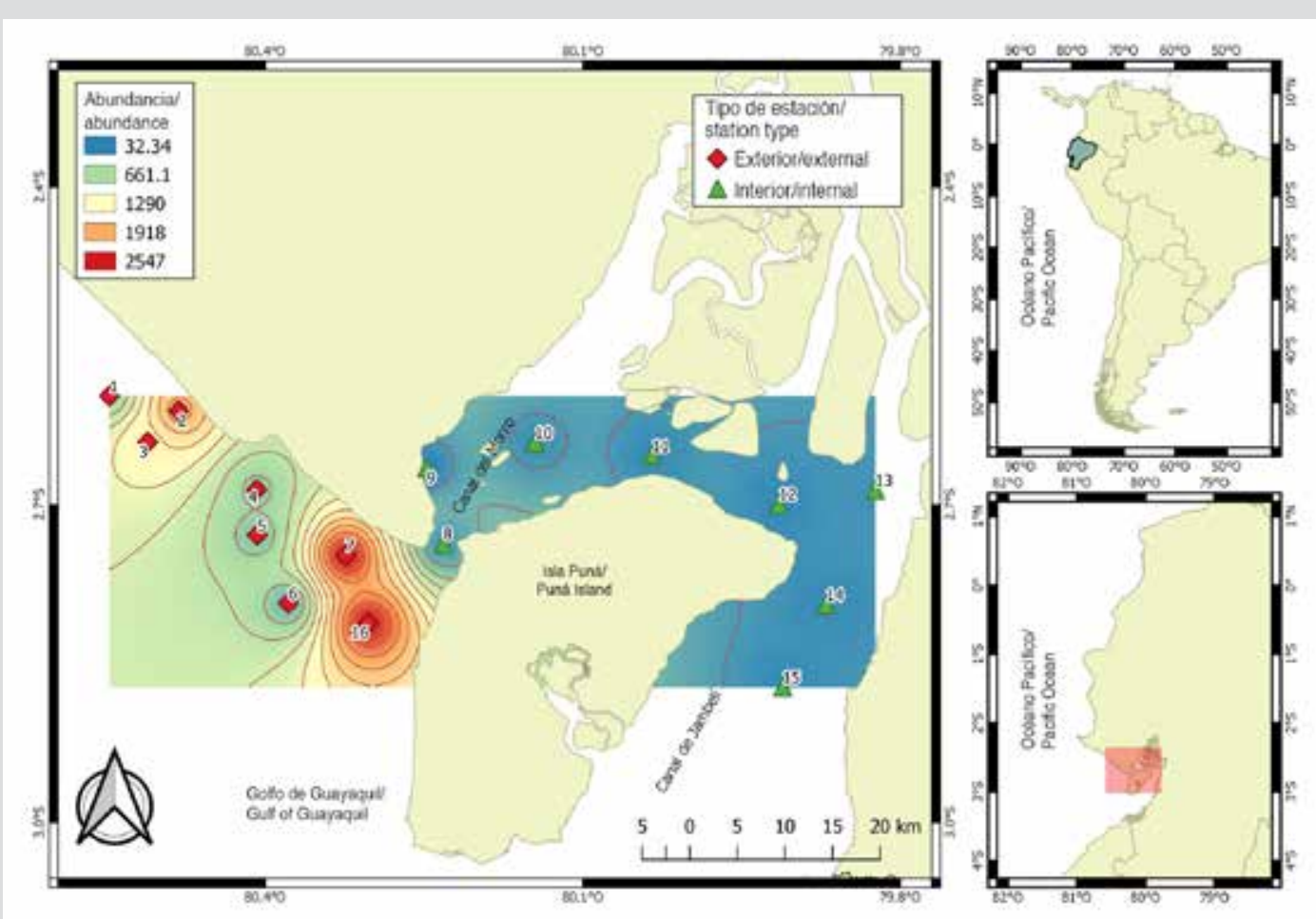

Figura 4. Variabilidad espacial de la abundancia de larvas de peces en el estuario exterior e interior del golfo de Guayaquil frente a la provincia del Guayas.
Figure 4. Spatial variability of the abundance of fish larvae in the exterior and interior estuary of the Gulf of Guayaquil against the province of Guayas. 
La abundancia larval mostró variaciones temporales, con diferencias significativas entre los meses $(\mathrm{KW}=14,24 ; \mathrm{p}<0,05)$. Las máximas densidades de larvas correspondieron a diciembre (121 220 larvas $\left./ 100 \mathrm{~m}^{3}\right) \mathrm{y}$ julio (107 631 larvas/100 $\mathrm{m}^{3}$ ), mientras que la mínima fue registrada en noviembre (6 690 larvas $/ 100 \mathrm{~m}^{3}$ ). El patrón general exhibió mayores abundancias hacia el estuario exterior del golfo de Guayaquil, enmarcada hacia el inicio de la época seca (julio) y de transición (diciembre) (Figura 5 a y Figura 5b). Las especies larvales que caracterizaron la zona externa e interna fueron Anchoa sp. y Bairdiella sp., con altos valores durante diciembre, en tanto que Gobiosoma sp. y Haemulon sp. registraron máximas densidades durante julio, y Anchovia macrolepidota en agosto (Tabla 2).

Se identificó un total de 17 familias y 36 especies, de las cuales 34 concurrieron en las estaciones del estuario exterior y 16 en el estuario interior (Tabla 2). Un total de tres familias (Engraulidae, Gobiidae y Sciaenidae) estuvieron presentes consistentemente durante todos los meses de estudio. Las muestras en la zona externa estuvieron dominadas por larvas de las familias Engraulidae (58,9 \%), Sciaenidae $(22,8 \%)$ y Haemulidae $(9,6 \%)$, representadas por las especies Anchoa sp. (49,6\%), Bairdiella sp. (10,7\%) y Haemulon sp. (9,6\%), respectivamente. Mientras tanto, en el estuario interior, fueron Engraulidae (74,4 \%) y Gobiidae $(16,1 \%)$ los grupos más abundantes y representados en este mismo sentido por Anchoa sp., (56,2 \%), Anchovia macrolepidota (14,5\%) y Gobiosoma sp. (15,3\%). En general, los taxones Anchoa sp. (50,3\%). Bairdiella sp. (9,7\%) Anchovia macrolepidota (9,6\%), Haemulon sp. $(8,6 \%)$ y Gobiosoma sp. (7,0\%) representaron $85 \%$ del total de la densidad larval para las dos zonas de estudio (Tabla 2).

Tabla 2. Lista taxonómica de larvas de peces encontrados en el estuario exterior (E) e interior (I) del golfo de Guayaquil, durante julio a diciembre de 2012. Se indican la abundancia relativa (Ar. \%) y meses de ocurrencia de las larvas recolectadas las dos zonas de estudio.
Larval abundance showed temporal variations, with significant differences between months $(\mathrm{KW}=14.24$; $\mathrm{p}<0.05)$. The highest larval densities corresponded to December $\left(121,220\right.$ larvae/100 $\left.\mathrm{m}^{3}\right)$ and July $\left(107,631\right.$ larvae/100 $\left.\mathrm{m}^{3}\right)$, while the lowest was recorded in November $\left(6,690\right.$ larvae $\left./ 100 \mathrm{~m}^{3}\right)$. The general pattern exhibited greater abundances towards the exterior estuary of the Gulf of Guayaquil and framed towards the beginning of the dry season (July) and the transitional season (December) (Figure 5a and Figure 5b). The larval species that characterized the external and internal zone were Anchoa sp. and Bairdiella sp. with high values during December, while Gobiosoma sp. and Haemulon sp. registered maximum densities during July, and Anchovia macrolepidota in August (Table 2).

A total of 17 families and 36 species were identified, of which 34 concurred in the stations of the exterior estuary and 16 in the interior estuary (Table 2). A total of three families (Engraulidae, Gobiidae, and Sciaenidae) were consistently present during all the months of the study. The samples in the external zone were dominated by larvae of the families Engraulidae (58.9\%), Sciaenidae (22.8\%) and Haemulidae (9.6 \%), represented by the species Anchoa sp. (49.6\%), Bairdiella sp. (10.7\%) and Haemulon sp. $(9.6 \%)$, respectively. While in the interior estuary, they were Engraulidae (74.4\%) and Gobiidae (16.1\%), the most abundant groups and represented in this sense by Anchoa sp. (56.2\%), Anchovia macrolepidota (14.5\%) and Gobiosoma sp. (15.3\%). In general, the taxa Anchoa sp. (50.3\%). Bairdiella sp. (9.7\%) Anchovia macrolepidota (9.6\%), Haemulon sp. (8.6\%), and Gobiosoma sp. (7.0\%) represented $85 \%$ of the total larval density for the two study areas (Table 2).

\begin{tabular}{|c|c|c|c|c|c|c|c|c|c|}
\hline \multirow{2}{*}{ Taxón/Taxon } & \multirow{2}{*}{ Ar. $\%(E)$} & \multirow{2}{*}{ Ar. $\%(I)$} & \multicolumn{7}{|c|}{ Meses/Months } \\
\hline & & & $\mathrm{J}$ & $\mathrm{J}$ & $\mathrm{A}$ & $\mathrm{S}$ & $\mathrm{O}$ & $\mathrm{N}$ & $\mathrm{D}$ \\
\hline Achiridae & 0.07 & 0.1 & & & & & & & \\
\hline Achirus mazatlanus & 0.05 & 0.1 & & 139 & & & 35 & & \\
\hline Achirus sp. & 0.02 & & & & & & & & 70 \\
\hline Blenniidae & 2.01 & 0.2 & & & & & & & \\
\hline Hypsoblennius sp. 1 & 0.24 & & & & 697 & & & & \\
\hline Hypsoblennius sp. & 1.77 & & 906 & 1847 & & 592 & 1742 & 70 & \\
\hline
\end{tabular}

Table 2. Taxonomic list of fish larvae found in the exterior (E) and interior (I) estuary of the Gulf of Guayaquil, from July to December 2012. The relative abundance (Ar. \%) and months of the occurrence of the larvae collected from the two study areas. 


\begin{tabular}{|c|c|c|c|c|c|c|c|c|c|}
\hline \multirow{2}{*}{ Taxón/Taxon } & \multirow{2}{*}{ Ar. $\%(E)$} & \multirow{2}{*}{ Ar. $\%$ (I) } & \multicolumn{7}{|c|}{ Meses/Months } \\
\hline & & & $\mathrm{J}$ & $\mathrm{J}$ & A & S & $\mathrm{O}$ & $\mathrm{N}$ & $\mathrm{D}$ \\
\hline Carangidae & 0.5 & & & & & & & & \\
\hline Chloroscombrus orqueta & 0.04 & & 70 & & & 35 & & & \\
\hline Oligoplites saurus & 0.02 & & 70 & & & & & & \\
\hline Seriola lalandi & 0.06 & & & & 174 & & & & \\
\hline Seriola sp. & 0.23 & & 279 & 105 & & 279 & & & \\
\hline Trachurus sp. & 0.15 & & 418 & & & & & & \\
\hline Clupeidae & 0.24 & & & & & & & & \\
\hline Etrumeus acuminatus & 0.12 & & 348 & & & & & & \\
\hline Opisthonema sp. & 0.12 & & & 348 & & & & & \\
\hline Dactyloscopidae & 0.32 & & & & & & & & \\
\hline Dactyloscopus pectoralis & 0.19 & & & & 105 & & 348 & & 105 \\
\hline Dactyloscopus sp. & 0.12 & & & & & & & 348 & \\
\hline Engraulidae & 58.9 & 74.4 & & & & & & & \\
\hline Anchoa sp. & 49.63 & 56.24 & 10244 & 42787 & 2125 & 15923 & 1185 & 2787 & 86829 \\
\hline Anchovia macrolepidota & 9.01 & 14.52 & 2787 & 6341 & 12544 & 523 & 4390 & 1394 & 2892 \\
\hline Cetengraulis mysticetus & 0.01 & 3.78 & & & 1080 & & 209 & & 35 \\
\hline Engraulis ringens & 0.24 & & 697 & & & & & & \\
\hline Gerreidae & 2.62 & & & & & & & & \\
\hline Eucinostomus gracilis & 2.5 & & 976 & 4564 & 105 & 488 & 697 & & 348 \\
\hline Eucinostomus sp. & 0.12 & & & 348 & & & & & \\
\hline Gobiesocidae & & 0.51 & & & & & & & \\
\hline Gobiesox sp. & & 0.51 & & & 139 & & & 35 & \\
\hline \multicolumn{10}{|l|}{ Gobiidae } \\
\hline Gobionellus sp. & & 0.82 & 70 & & & & & 209 & \\
\hline Gobiosoma sp. & 0.91 & 15.34 & 1394 & 1847 & 383 & 1777 & 1220 & 1115 & 105 \\
\hline Haemulidae & 9.62 & 0.31 & & & & & & & \\
\hline Haemulon sp. & 9.62 & 0.31 & 1882 & 21254 & 3554 & & 383 & & 697 \\
\hline Labrisomidae & 0.23 & 0.51 & & & & & & & \\
\hline Labrisomus sp. & 0.23 & 0.51 & & 244 & 35 & & & 383 & 174 \\
\hline Mugilidae & 0.02 & & & & & & & & \\
\hline Mugil cephalus & 0.02 & & 70 & & & & & & \\
\hline Nomeidae & 0.24 & & & & & & & & \\
\hline Nomeus sp. & 0.24 & & 697 & & & & & & \\
\hline Sciaenidae & 22.78 & 7.76 & & & & & & & \\
\hline Bairdiella sp. & 10.7 & 1.94 & 2091 & 383 & & & 348 & & 28606 \\
\hline Cynoscion sp. & 1.77 & 2.86 & 2718 & 3310 & & & & & 35 \\
\hline Larimus sp. & 0.74 & 2.15 & 836 & 70 & 139 & 279 & 348 & & 1185 \\
\hline Menticirrhus sp. & 0.28 & 0.21 & & & 70 & 662 & & & 139 \\
\hline Micropogonias altipinnis & 7.88 & & & 22648 & & & & & \\
\hline Stellifer sp. & 1.42 & 0.61 & 139 & 348 & & 3449 & & 348 & \\
\hline Serranidae & 1.48 & & & & & & & & \\
\hline Diplectrum sp. & 0.24 & & & 697 & & & & & \\
\hline Paralabrax sp. & 1.24 & & & 348 & & 3206 & & & \\
\hline Synodontidae & 0.01 & & & & & & & & \\
\hline Synodus lucioceps & 0.01 & & & & & 35 & & & \\
\hline Tetraodontidae & 0.05 & 0.1 & & & & & & & \\
\hline Sphoeroides lobatus & 0.05 & & 139 & & 35 & & & & \\
\hline
\end{tabular}


La riqueza específica varió de 9 especies en noviembre a 20 en junio con un promedio temporal de 13 especies $( \pm 3,89)$. Se observaron diferencias significativas entre zonas (MW-U: 325; p < 0,05), mostrando la mayor riqueza en el estuario exterior con similar tendencia que la abundancia larval registrada (Figura 5c y Figura 5d).

La diversidad larval ( $\left.\mathrm{H}^{\prime}\right)$ varió significativamente entre las zonas de estudio (MW-U: 2655; p < 0,05), registrándose valores mínimos en el estuario interno durante septiembre $(0,81$ bits/ind) y máximo en agosto ( 1,5 bits/ind). En el estuario exterior durante junio (2,32 bits/ind) se observó la mayor diversidad y en diciembre ( 0,74 bits/ind), la menor (Figura 5e y Figura 5f). En general, la diversidad observada en la zona interna tuvo un comportamiento más constante en el tiempo en comparación con las registradas en la zona externa (Figura 5e y Figura 5f).
The specific richness varied from 9 species in November to 20 in June with a temporal average of 13 species $( \pm$ 3.89). Significant differences were observed between zones (MW-U: $325 ; \mathrm{p}<0.05$ ), showing the greatest wealth in the exterior estuary with a similar trend as the recorded larval abundance (Figure 5c and Figure 5d).

Larval diversity $\left(\mathrm{H}^{\prime}\right)$ varied significantly between study areas (MW-U: 2655; $\mathrm{p}<0.05$ ), with minimum values being recorded in the internal estuary during September (0.81 bits/ind) and maximum in August (1.5 bits/ind). In the exterior estuary during June ( 2.32 bits/ind), the highest diversity was observed and in December ( 0.74 bits/ind), the lowest (Figure 5e and Figure 5f). In general, the diversity observed in the internal zone had more constant behavior over time compared to those registered in the external zone (Figure 5e and Figure 5f).

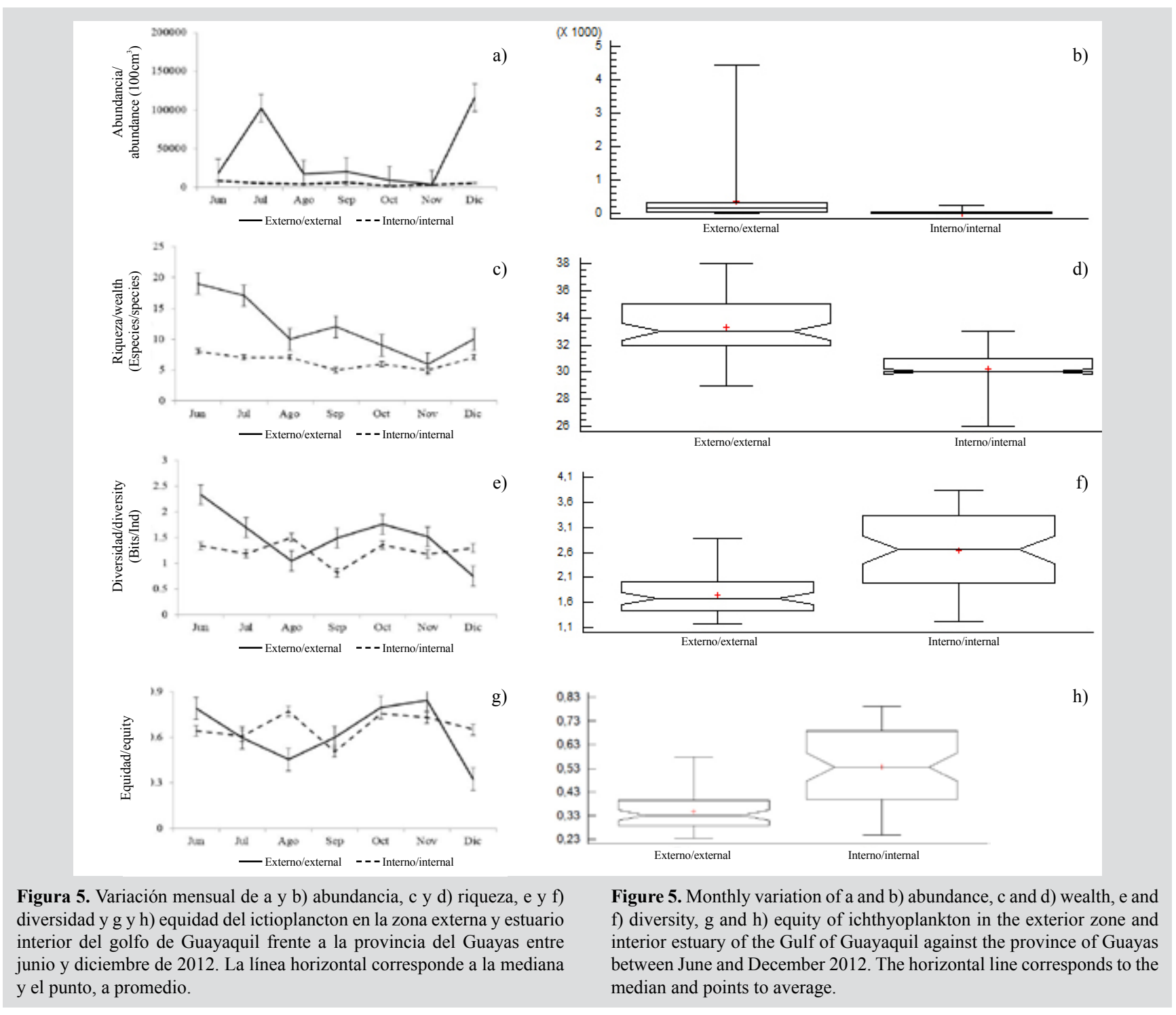


La equidad mínima $(0,31)$ se observó en diciembre y la máxima, en octubre $(0,77)$. Entre zonas se presentaron diferencias significativas (MW-U: 2702, p $<0,05$ ), mostrando una mayor homogeneidad en la zona estuarina (Figura $5 \mathrm{~g}$ y Figura $5 \mathrm{~h}$ ).

Al explorar las relaciones de similitud (MDS Anosim) entre las comunidades de ictioplancton se establecieron diferencias significativas (R: 0,$62 ; \mathrm{p}<0,05$ ) entre las zonas externa e interna del golfo de Guayaquil. No obstante, se observa que hay especies que se encuentran en ambas zonas y muestran una mayor heterogeneidad en las estaciones internas con un estrés de 0,11 (Figura 6). $\mathrm{Al}$ realizar el análisis de porcentajes de similitud (Simper) para explorar los aspectos de la estructura interna de las zonas del estuario interior y exterior, se notaron diferencias entre las dos, distinguiéndose a Anchoa spp., Haemulon sp., Anchovia macrolepidota como las especies que más contribuyeron a separar las zonas (Tabla 3).
The minimum equity (0.31) was observed in December and the maximum in October (0.77). There were significant differences between zones (MW-U: 2702, $\mathrm{p}<0.05$ ), showing greater homogeneity in the estuarine zone (Figure $5 \mathrm{~g}$ and Figure $5 \mathrm{~h}$ ).

When exploring the similarity relationships (MDS Anosim) between the ichthyoplankton communities, significant differences (R: $0.62 ; \mathrm{p}<0.05$ ) were established between the external and internal zones of the Gulf of Guayaquil. However, it is observed that there are species found in both zones and that showed a greater heterogeneity in the internal stations with the stress of 0.11 (Figure 6). When performing the percentage similarity analysis (SIMPER) to explore aspects of the internal structure of the interior and exterior estuary areas, differences were noted between the two, distinguishing Anchoa spp., Haemulon sp., Anchovia macrolepidota as the species that contributed the most to separating the areas (Table 3).

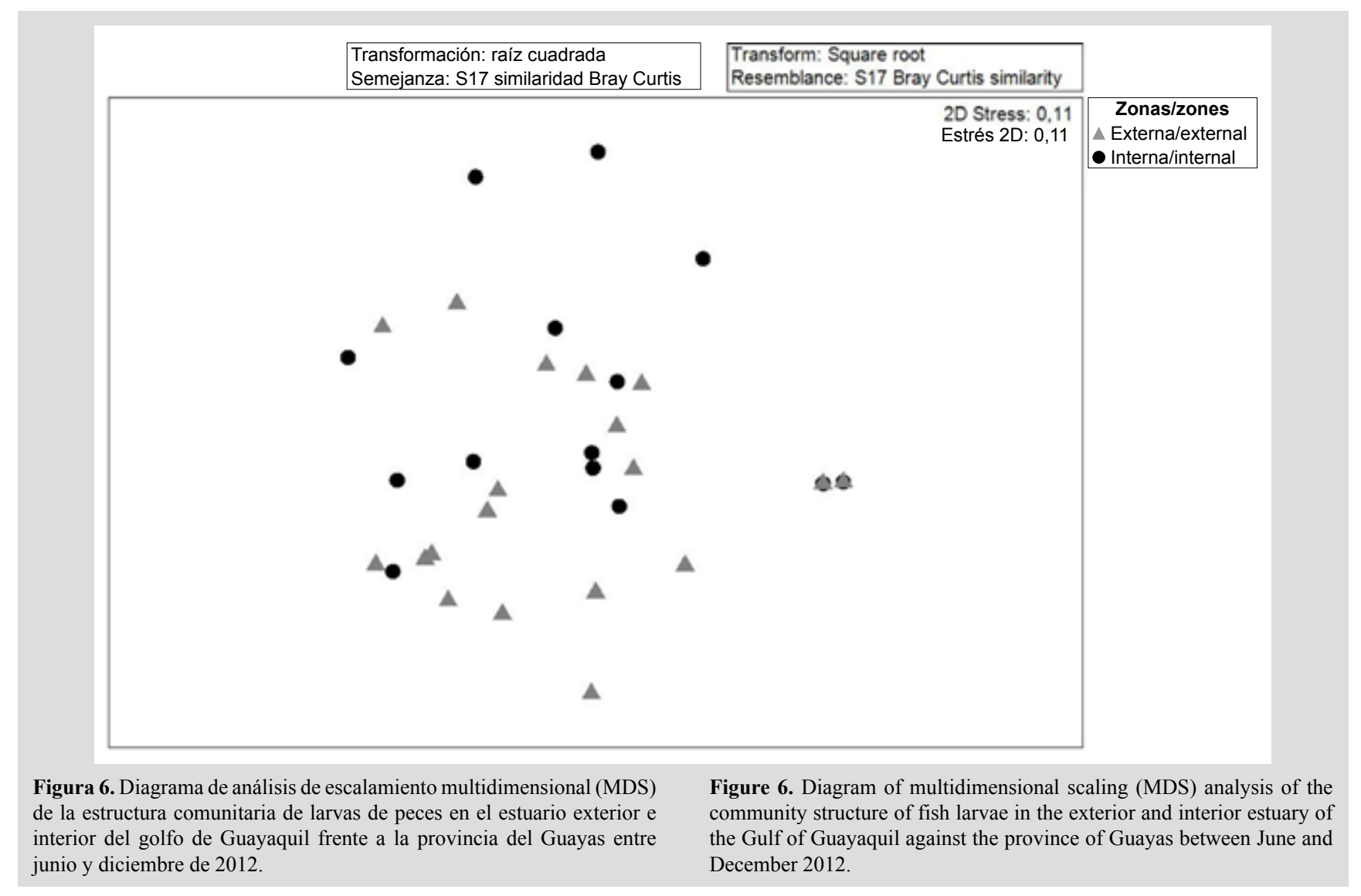


Tabla 3. Resumen del análisis Simper de las especies de ictioplancton en el estuario exterior e interior del golfo de Guayaquil frente a la provincia del Guayas entre junio y diciembre de 2012.
Table 3. Summary of the SIMPER analysis of the ichthyoplankton species in the exterior and interior estuary of the Gulf of Guayaquil against the province of Guayas between June and December 2012.

\begin{tabular}{|c|c|c|c|c|}
\hline \multirow[b]{2}{*}{ Especies/Species } & Estuario exterior/Exterior estuary & Estuario interior/Interior estuary & \multirow{2}{*}{$\begin{array}{c}\text { Contribución/ } \\
\text { Contribution (\%) }\end{array}$} & \multirow{2}{*}{$\begin{array}{c}\text { Acumulación/ } \\
\text { Accumulation (\%) }\end{array}$} \\
\hline & $\begin{array}{l}\text { Abundancia promedio/ } \\
\text { Average abundance }\end{array}$ & $\begin{array}{l}\text { Abundancia promedio/Average } \\
\text { abundance }\end{array}$ & & \\
\hline Anchoa sp. & 118.66 & 43.8 & 17.85 & 17.85 \\
\hline Haemulon $\mathrm{sp}$. & 45.51 & 3.66 & 9.81 & 27.66 \\
\hline Anchovia macrolepidota & 49.46 & 24.06 & 9.49 & 37.16 \\
\hline Micropogonias altipinnis & 37 & 0 & 8.51 & 45.67 \\
\hline Bairdiella sp. & 38.03 & 8.76 & 7.66 & 53.33 \\
\hline Hypsoblennius sp. & 20.88 & 4.32 & 4.97 & 58.3 \\
\hline Gobiosoma sp. & 7.35 & 22.67 & 4.94 & 63.24 \\
\hline Eucinostomus gracilis & 22.6 & 1.61 & 4.86 & 68.1 \\
\hline Stellifer $\mathrm{sp}$ & 20.52 & 3.88 & 4.38 & 72.48 \\
\hline Cynoscion sp. & 12.76 & 10.1 & 3.57 & 76.05 \\
\hline
\end{tabular}

\section{Relación entre larvas de peces y variables ambientales}

El análisis de redundancia (RDA) permitió estudiar la relación entre la estructura de ictioplancton y las variables ambientales del estuario interior y exterior. El RDA para la zona exterior explicó $14,0 \%$ de la varianza total en los dos primeros ejes, con una correlación de Pearson de $r=0,50$, indicando la correlación positiva de las especies y las variables ambientales (Tabla 4). El primer eje explicó $12,1 \%$ de la varianza y presentó un eigenvalor de 0,54 . La variable transparencia $(\mathrm{m})$ registró correlación negativa alcanzando el valor de $r=-0,63$. El eje dos solo contribuyó con $1,9 \%$ y presentó un eigenvalor de 0,50 , registrando la salinidad con correlación negativa de $r=-0,53$ (Tabla 4). El diagrama de dispersión muestra que las especies como Etrumeus acuminatus, Achirus mazatlanus, Sphoroiedes lobatus, Oligoplites saurus Diplectrum sp., se asociaron a una mayor transparencia del agua. En tanto que las especies como Gobiosoma sp., Labrisomus sp., Larimus sp., Cynoscion sp., Synodus lucioceps, Eucinostomus gracilis, Seriola lalandi y Stellifer sp. se relacionaron con valores altos de salinidad (Figura 7a).

Para la zona interna, el RDA explicó una varianza en los dos primeros ejes de 19,4\%, con un coeficiente de correlación de Pearson de $r=0,71$. El primer eje fue el que más contribuyó con $15,5 \%$ de la varianza explicada y un eigenvalor de 0,87 (Tabla 4). La variable salinidad registró correlación negativa con valor de $\mathrm{r}=-0,56$. El eje dos tan solo aportó 3,9\% del total y presentó un eigenvalor de 0,63. La variable transparencia registró correlación negativa de $r=-0,63$ con respecto a este eje (Tabla 4). El diagrama

\section{Relationship between fish larvae} and environmental variables

The redundancy analysis (RDA) allowed studying the relationship between the structure of ichthyoplankton and the environmental variables of the interior and exterior estuary. The RDA for the exterior zone explained $14.0 \%$ of the total variance in the first two axes, with a Pearson correlation of $r=0.50$, indicating the positive correlation of the species and the environmental variables (Table 4). The first axis explained $12.1 \%$ of the variance and presented an eigenvalue of 0.54 . The transparency variable $(\mathrm{m})$ registered a negative correlation, reaching the value of $r=-0.63$. Axis two only contributed $1.9 \%$ and presented an eigenvalue of 0.50 , registering salinity with a negative correlation of $r=-0.53$ (Table 4). The scatter diagram shows that species such as Etrumeus acuminatus, Achirus mazatlanus, Sphoroiedes lobatus, Oligoplites saurus Diplectrum sp. were associated with increased water transparency. While species such as Gobiosoma sp., Labrisomus sp., Larimus sp., Cynoscion sp., Synodus lucioceps, Eucinostomus gracilis, Seriola lalandi and Stellifer sp. were related to high salinity values (Figure 7a).

For the internal zone, the RDA explained variance in the first two axes of $19.4 \%$, with a Pearson's correlation coefficient of $r=0.71$. The first axis was the one that contributed the most with $15.5 \%$ of the explained variance and an eigenvalue of 0.87 (Table 4 ). The salinity variable registered a negative correlation with a value of $r=-0.56$. Axis two only contributed $3.9 \%$ of the total and presented an eigenvalue of 0.63 . The transparency variable registered a negative correlation of $r=-0.63$ to this axis (Table 4 ). The 
de dispersión muestra que Gobiesox sp. y Haemulon sp. se asociaron con altas concentraciones de salinidad. Los taxas como Bairdiella sp., Labrisomus sp. y Larimus sp. se relacionaron con las estaciones de mayor trasparencia. En contraste, Anchoa sp. Anchovia macrolepidota, Gobiosoma sp. y Cetengraulis mysticetus se asociaron con valores bajos de salinidad (Figura 7b).

Tabla 4. Análisis de redundancia sobre la relación espacial de las especies de ictioplancton en el estuario exterior e interior del golfo de Guayaquil frente a la provincia del Guayas entre junio y diciembre de 2012. scatter diagram shows that Gobiesox sp. and Haemulon sp. were associated with high concentrations of salinity. Taxes such as Bairdiella sp., Labrisomus sp. and Larimus sp. were related to the stations with the highest transparency. In contrast, Anchoa sp., Anchovia macrolepidota, Gobiosoma sp. and Cetengraulis mysticetus were associated with low salinity values (Figure 7b).

Table 4. Redundancy analysis on the spatial relationship of the ichthyoplankton species in the exterior and interior estuary of the Gulf of Guayaquil against the province of Guayas between June and December 2012.

\begin{tabular}{|c|c|c|c|c|c|c|}
\hline \multirow{2}{*}{ Estadístico/Statistical } & \multicolumn{3}{|c|}{ Estuario exterior/Exterior estuary } & \multicolumn{3}{|c|}{ Estuario interior/Interior estuary } \\
\hline & Eje/Axe 1 & Eje/Axe 2 & Eje/Axe 3 & Eje/Axe 1 & Eje/Axe 2 & Eje/Axe 3 \\
\hline Eigenvalor/Eigenvalue & 0.54 & 0.50 & 0.38 & 0.87 & 0.63 & 0.35 \\
\hline Varianza explicada/Variance explained (\%) & 12.1 & 1.9 & 1.5 & 15.1 & 3.9 & 2.2 \\
\hline Varianza acumulada/Cumulative variance (\%) & 12.1 & 14.0 & 15.5 & 15.1 & 19.4 & 21.6 \\
\hline $\begin{array}{l}\text { Correlación de Pearson (especies-ambiente)/ } \\
\text { Pearson's correlation (species-environment) }\end{array}$ & 0.59 & 0.55 & 0.32 & 0.72 & 0.71 & 0.54 \\
\hline Valores de correlación/Correlation values & \multicolumn{3}{|c|}{ Estuario exterior/Exterior estuary } & \multicolumn{3}{|c|}{ Estuario interior/Interior estuary } \\
\hline Variables & Eje/Axe 1 & Eje/Axe 2 & Eje/Axe 3 & Eje/Axe 1 & Eje/Axe 2 & Eje/Axe 3 \\
\hline Transparencia del agua/Water transparency (M) & -0.63 & 0.37 & 0.39 & 0.31 & -0.63 & 0.09 \\
\hline Salinidad superficial del mar/Sea surface salinity (SSM) & -0.57 & -0.53 & -0.75 & -0.56 & -0.43 & -0.11 \\
\hline Temperatura superficial del mar/Sea surface temperature (TSM) & -0.56 & -0.33 & 0.62 & 0.31 & 0.15 & 0.48 \\
\hline
\end{tabular}

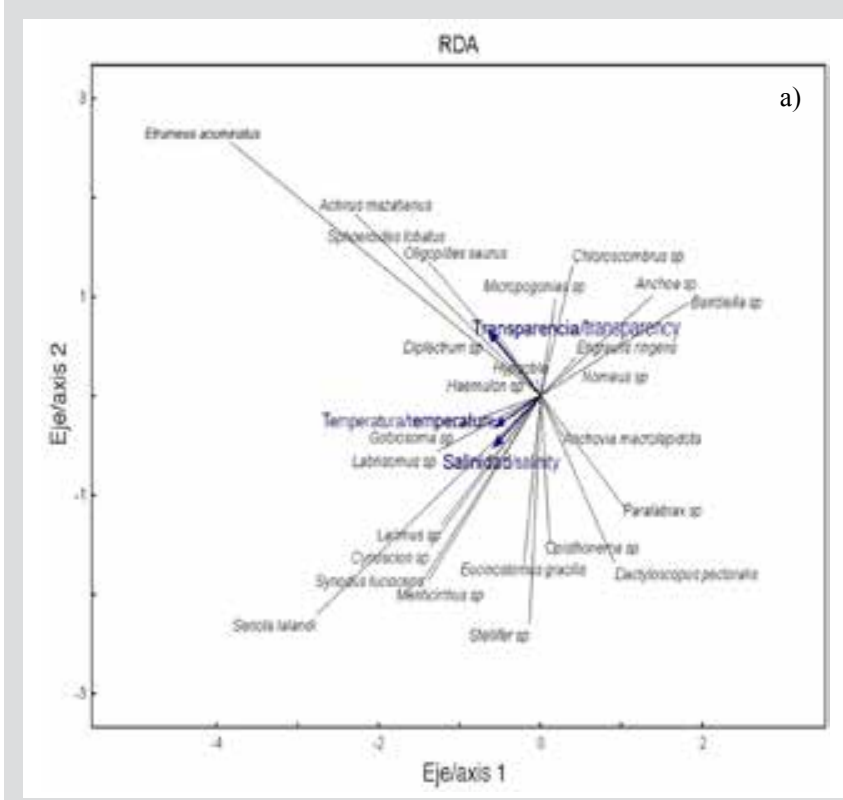

Figura 7. Diagrama de dispersión de larvas de peces en el estuario exterior a) y estuario interior b) del golfo de Guayaquil frente la provincia del Guayas entre junio y diciembre 2012. Temperatura (TSM). Salinidad (SSM). Transparencia (M).

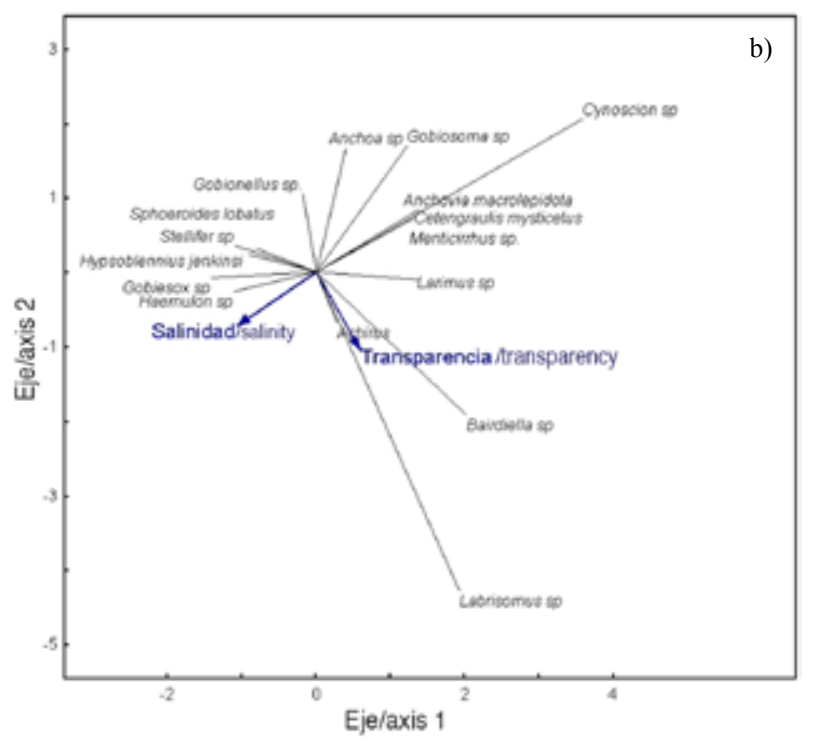

Figure 7. Scatter diagram of fish larvae in the exterior estuary a) and interior estuary b) of the Gulf of Guayaquil in front of the province of Guayas between June and December 2012. Temperature (SST). Salinity (SSM). Transparency (M). 


\section{DISCUSIÓN Y CONCLUSIONES}

En el presente estudio, las diferencias de las condiciones hidrográficas del golfo de Guayaquil en el estuario exterior e interior son claras, evidenciadas por las relaciones de temperatura, salinidad y transparencia. Una zona externa, donde la influencia oceánica es evidente — con menor temperatura, mayor salinidad y transparencia - con respecto a la zona interna del golfo, donde la profundidad se reduce por el gran aporte sedimentario, los procesos de mezcla aumentan y la salinidad disminuye, especialmente durante la estación seca, producto del flujo de mareas (semidiurno) influenciado por el aporte de agua dulce del río Guayas (Stevenson, 1981) y, en conjunto, regulada por las fluctuaciones estacionales de la época seca, con temperaturas frías a partir de julio a noviembre, oscilación normal dada la intensificación de la corriente fría de Humboldt que avanza desde el sur hacia la costa del Ecuador, desplazando sus aguas frías, salinas y ricas en nutrientes para estos meses.

Nuestros resultados muestran características similares a las observadas en otros estudios realizados en el golfo de Guayaquil o áreas adyacentes (Cajas e Hinostroza, 1981; Ortega y Elías, 1996; Torres et al., 2003; Elías et al., 2007; Calderón et al., 2018; Salcedo y Coello, 2018), con densidades larvales relativamente altas en la zona externa del golfo, con predominancia de larvas de engráulidos y baja diversidad larval. La mayor abundancia larval se registró en la parte exterior del golfo, específicamente en las estaciones colindantes al canal del Morro, donde al parecer la temperatura, salinidad y transparencia del agua fueron más estables; por tanto, podrían haber favorecido el desarrollo de huevos y larvas de peces (Saborido, 2008). Otro elemento que pudo contribuir a dicha distribución es la combinación de ambientes en los sitios externos, como fondos rocosos y/o arenosos y la mayor influencia marina, los cuales permiten que mayor diversidad de adultos se agrupen, ya sea con fines reproductivos, alimentación o de refugio (Whitfield, 1999), y afecten así la composición y abundancia del ictioplancton. Por ejemplo, en estos sitios aparecieron especies como Hypsoblennius sp. 1, que habitan principalmente fondos rocosos y únicamente fueron encontrados en los sitios externos. A medida que se ingresa en el estuario interior, se observa que las densidades larvales decrecen como respuesta a varios factores, entre ellos la topografía del fondo, que incide sobre las mareas y la turbulencia, puesto que, al disminuir la profundidad, aumentan los procesos de mezcla y reducen la fotosíntesis por la presencia de partículas suspendidas y disueltas (Prado

\section{DISCUSSION AND CONCLUSIONS}

In the present study, the differences in the hydrographic conditions of the Gulf of Guayaquil in the exterior and interior estuary are clear, evidenced by the relationships of temperature, salinity, and transparency. An external zone, where the oceanic influence is evident - with a lower temperature, greater salinity, and transparency - to the internal zone of the gulf, where the depth is reduced by the great sedimentary contribution, the mixing processes increase and the salinity decreases, especially during the dry season, as a result of the tidal flow (semi-day) influenced by the supply of freshwater from the Guayas River (Stevenson, 1981) and, as a whole, regulated by seasonal fluctuations of the dry season, with cold temperatures from July to November, normal oscillation, given the intensification of the cold Humboldt current that advances from the south to the coast of Ecuador, displacing its cold, saline and nutrientrich waters for these months.

Our results showed characteristics similar to those observed in other studies carried out in the Gulf of Guayaquil or adjacent areas (Cajas and Hinostroza, 1981; Ortega and Elías, 1996; Torres et al., 2003; Elías et al., 2007; Calderón et al., 2018; Salcedo and Coello, 2018), with relatively high larval densities in the external area of the gulf, with a predominance of engulid larvae and low larval diversity. The greatest larval abundance was registered in the exterior part of the gulf, specifically in the stations adjacent to the Morro channel, where the temperature, salinity, and transparency of the water were more stable; therefore, they could have favored the development of fish eggs and larvae (Saborido, 2008). Another element that could contribute to said distribution is the combination of environments in external sites, such as rocky and/or sandy bottoms and the greater marine influence, which allow a greater diversity of adults to group, whether for reproductive purposes, food or refuge (Whitfield, 1999), thus affecting the composition and abundance of ichthyoplankton. For example, species such as Hypsoblennius sp. 1 appeared in these sites, which mainly inhabit rocky bottoms and were only found in external sites. As one enters the inland estuary, it is observed that larval densities decrease as a response of several factors, among them the bottom topography, which affects the tides and turbulence since the depth decreases, the mixing processes and photosynthesis reduces due to the presence of suspended and dissolved particles (Prado and Buchelli, 2012), which results in reduced food and less presence of fish larvae. 
y Buchelli, 2012), lo que se traduce en un reducido alimento y en menor presencia de larvas de peces.

Una de las características distintivas de los ensamblajes de larvas de peces en estuarios tropicales es la dominancia de pocas especies, las cuales generalmente aparecen asociadas a un alto número de especies en baja abundancia que frecuentan el estuario de manera ocasional (Whitfield, 1989, 1999; Morais, 1994; Barletta-Bergan et al., 2002; Barletta y Barletta-Bergan, 2009). En el golfo de Guayaquil se observa esta condición, ya que estuvo dominado por larvas de tres familias de peces: engráulidos, sciánidos y góbidos, coincidente con lo descrito por Calderón et al. (2018) y Salcedo y Coello (2018).

Así mismo, en los sistemas heterogéneos existe una alta variedad de especies de peces con distintos requerimientos $\mathrm{y} / \mathrm{o}$ patrones de desove, donde algunas especies se reproducen durante todo el año y otras exhiben uno o dos picos de reproducción (Pittman et al., 2004). Con base en esto, en el golfo, la variabilidad temporal encontrada puede reflejar los diferentes patrones reproductivos que presentan las especies que, como adultos, habitan en este sistema. Los engráulidos, representados principalmente por Anchoa sp., sobresalieron con máximas densidades en toda el área - tanto en la zona interna como externa- y meses de estudio, lo que sugiere que su presencia como estadio larval no es estacional, y que probablemente en esta área de estudio se reproduzca varias veces al año, pudiendo desovar en la zona externa para que sus larvas ingresen y se desarrollen en el estuario interior (Day et al., 1989; Whitfield, 1999). Igualmente, su distribución estaría explicada por ser una familia al igual que Gobiidae de hábitat salobre-marino (Whitehead et al., 1988; Whitehead y Rodríguez-Sánchez, 1995), las cuales son reportadas regularmente en estuarios o bahías (Silva-Segundo et al., 2008). Mientras tanto, aquellos estadios larvales que solo fueron registrados en una área y/o mes de muestreo — como por ejemplo los sciánidos, especies demersales, estuario-dependientes, con desoves en áreas costeras, estuarios y bahías (Ocaña-Luna y Sánchez Ramírez, 2003) y que migran desde el área de puesta a las desembocaduras de las zonas de crianza- podrían corresponder a especies con un solo período reproductivo anual en el área externa del golfo.

La diversidad varió en el espacio y en el tiempo. En el estuario interior se registró la mayor diversidad larval, observándose una relación inversa entre la abundancia y riqueza de especies. Esto sugiere un importante intercambio
One distinguishing characteristic of fish larvae assemblages in tropical estuaries is the dominance of few species, which generally appear associated with a high number of species in low abundance that occasionally frequent the estuary (Whitfield, 1989, 1999; Morais, 1994; Barletta-Bergan et al., 2002; Barletta and Barletta-Bergan, 2009). This condition is observed in the Guayaquil Gulf since it was dominated by larvae of three fish families: engulid, scianid and gobiidae, coinciding with that described by Calderón et al. (2018) and Salcedo and Coello (2018).

Likewise, in heterogeneous systems, there is a high variety of fish species with different requirements and/or spawning patterns, where some species reproduce throughout the year and others exhibit one or two reproductive peaks (Pittman et al., 2004). Based on this, in the gulf, the temporal variability found can reflect the different reproductive patterns that species that inhabit this system as adults present. The engulids, mainly represented by Anchoa sp., stood out with maximum densities in the entire area - both in the internal and external zones - and months of study, which suggests that their presence as a larval stage is not seasonal, and that probably in this study area reproduces several times a year, being able to spawn in the external zone, so that its larvae enter and develop in the interior estuary (Day et al., 1989; Whitfield, 1999). Likewise, its distribution would be explained by being a family-like Gobiidae of brackish-marine habitat (Whitehead et al., 1988; Whitehead and Rodríguez-Sánchez, 1995), which are regularly reported in estuaries or bays (SilvaSegundo et al., 2008). Meanwhile, those larval stages that were only recorded in a sampling area and/or month - such as scianids, demersal, estuary-dependent species, with spawning in coastal areas, estuaries and bays (OcañaLuna and Sánchez Ramírez, 2003) and that migrate from the laying area to the mouths of the breeding areas - could correspond to species with a single annual reproductive period in the external area of the gulf.

Diversity varied in space and time. The largest larval diversity was recorded in the interior estuary, observing an inverse relationship between species abundance and richness. This suggests an important exchange and mix of marine and estuary species. In relation, Day et al. (1989) and McLusky and Elliot (2004) pointed out that it is common that in areas with marine influence, the richness of zooplankton organisms is greater, particularly in the mouth, forming a mixed community. On the other hand, other authors point out that internal areas favor larval aggregation by providing 
y mezcla de especies marinas y del estuario. En relación, Day et al. (1989) y McLusky y Elliot (2004) señalaron que es común que en áreas con influencia marina, la riqueza de organismos del zooplancton sea mayor, particularmente en la bocana, conformando una comunidad mixta. Por otro lado, otros autores señalan que las áreas internas favorecen la agregación larval por brindar condiciones de refugio y alimentación, relacionadas con una mayor turbidez, las grandes raíces de manglar y la alta sedimentación debida a la descarga de agua de los esteros (Barletta-Bergan et al., 2002; Barletta y Barletta-Bergan, 2009). Sin embargo, no necesariamente es un reflejo de la diversidad larval en cada zona, debido a que no todas las etapas larvarias ocupan esta área permanentemente, ya que un alto número de ellas son arrastradas por las corrientes de mareas (Neira y Potter, 1992; Ramos et al., 2005), dado que su locomoción es limitada en las primeras etapas de vida (Jiménez, 2008).

En cuanto a la riqueza de especies, es posible identificar un incremento en las estaciones con mayor influencia marina (estuario exterior), pero en la boca del canal del Moro (estación ocho y nueve) el pulso es máximo como reflejo de un alto tránsito de especies, que coinciden con la distribución de la salinidad, variable que juega un rol importante en la distribución y los procesos reproductivos de las especies. Esto no solo evidencia las estrategias biológicas y ecológicas especializadas que poseen las especies - como por ejemplo Anchoa sp., que posee condiciones para moverse en zonas de gran variabilidad ambiental (Yáñez-Arancibia et al., 1985)—, sino que también revela a este sitio como zona importante de reclutamiento de muchas especies, que aprovechan las condiciones propicias que ofrece este sistema como son alta productividad biológica y el refugio del ambiente como área de cría y puesta.

$\mathrm{Si}$ bien se conoce que generalmente en zonas estuarinas tropicales, la distribución espacio-temporal de peces adultos y juveniles está influenciada por los cambios en los factores ambientales (como temperatura y salinidad) (Laroche et al., 1997) y por la precipitación y cambios de mareas. Cada estuario presenta características morfológicas particulares como tipo de sustrato, distancia hacia el océano, etc., factores que también influyen en la estructura de las comunidades de peces (Pérez-Ruzafa et al., 2007).

Con base en ello, mediante el análisis de redundancia, se pudo observar que, para el golfo de Guayaquil, las relaciones larvales se dieron mayormente en torno a la turbidez y la salinidad del agua. En general, se considera que, para muchas especies marinas, los shelter and feeding conditions, related to greater turbidity, large mangrove roots and high sedimentation due to the discharge of water from the estuaries (Barletta-Bergan et al., 2002; Barletta and Barletta-Bergan, 2009). However, it is not necessarily a reflection of larval diversity in each zone, since not all larval stages occupy this area permanently since a high number of them are carried by tidal currents (Neira and Potter, 1992; Ramos et al., 2005), since their locomotion is limited in the early stages of life (Jiménez, 2008).

Regarding species richness, it is possible to identify an increase in the stations with the greatest marine influence (exterior estuary), but in the boca del Canal del Moro (station eight and nine) the pulse is maximum, reflecting high traffic of species, and that coincides with the distribution of salinity, a variable that plays an important role in the distribution and species reproductive processes. This not only evidences the specialized biological and ecological strategies that species possess - such as Anchoa sp., which has conditions to move in areas of great environmental variability (Yáñez-Arancibia et al., 1985) - , but also reveals this site as an important recruitment area for many species, which take advantage of the favorable conditions offered by this system, such as high biological productivity and the refuge of the environment as breeding and laying area.

Although it is known that generally in tropical estuarine areas, the spatio-temporal distribution of adult and juvenile fish is influenced by changes in environmental factors (such as temperature and salinity) (Laroche et al., 1997) and by precipitation and changes in tides. Each estuary presents particular morphological characteristics such as type of substrate, distance to the ocean, etc., factors that also influence the structure of fish communities (PérezRuzafa et al., 2007).

Based on this, utilizing the redundancy analysis, it was observed that for the Gulf of Guayaquil the larval relationships occurred mainly around the turbidity and salinity of the water. In general, larval and juvenile stages are considered to be more tolerant of environmental variability for many marine species than adults (Holliday, 1971). Larvae species such as Gobiosoma sp., Labrisomus sp., Larimus sp., Cynoscion sp., Synodus lucioceps, Haemulon sp., Eucinostomus gracilis, Seriola lalandi, Stellifer sp., Gobiesox sp., Anchoa sp., Anchovia macrolepidota, and Cetengraulis mysticetus, which are considered mostly estuarine species, were associated with high and low salinity. This suggests that these species show greater 
estadios larvales y juveniles resultan más tolerantes a la variabilidad ambiental que los adultos (Holliday, 1971). Las especies de larvas como Gobiosoma sp., Labrisomus sp., Larimus sp., Cynoscion sp., Synodus lucioceps, Haemulon sp., Eucinostomus gracilis, Seriola lalandi, Stellifer sp., Gobiesox sp., Anchoa sp., Anchovia macrolepidota, y Cetengraulis mysticetus, que son consideradas, en su mayoría, especies estuarinas, estuvieron asociadas con alta y baja salinidad. Lo anterior sugiere que estas especies evidencian mayor tolerancia a rangos de salinidad, por lo que muchas de ellas estuvieron presentes tanto en el ambiente estuarino como de influencia marina en tanto que especies como Etrumeus acuminatus, Achirus mazatlanus, Sphoeroiedes lobatus, Oligoplites saurus, Bairdiella sp., Diplectrum sp., Engraulis ringens y Opisthonema sp., las cuales en su mayoría pertenecen al componente marino como Etrumeus acuminatus, Engraulis ringens y Opisthonema sp., permanecieron en una zona o área. Específicamente en la zona externa se asociaron positivamente con la mayor transparencia, lo que refleja la preferencia de estas especies por características fisicoquímicas específicas.

Por lo tanto, es posible hipotetizar que, en un ambiente estuarino, la variación temporal de las condiciones ambientales estaría modulando la distribución, abundancia y, en general, la comunidad de larvas de peces. Así mismo, estas fluctuaciones estacionales y temporales representan las estrategias reproductivas de cada especie vinculadas a su hábitat (Sánchez, 1997), teniendo como premisa la disponibilidad de alimento para su supervivencia (Whitehead et al., 1988), dado que, frecuentemente, la abundancia de larvas de peces está estrechamente relacionada con la biomasa de zooplancton (Kaunda-Arara et al., 2009).

De acuerdo con los resultados obtenidos, el golfo de Guayaquil, al menos durante el período muestreado, presentó un ensamblaje de larvas de peces con una composición taxonómica integrada principalmente por la presencia de especies estuarinas con la dominancia de una familia (Engraulidae). Esta dominancia podría ser el resultado del efecto de varios factores físico-químicos, entre los que destacaron la salinidad, la transparencia y los eventos reproductivos de las especies presentes en el área, lo que permiten inferir que en general esta sección del golfo (área externa) es un área importante como salacuna para las especies. Sería interesante realizar más estudios y con muestreos más prolongados para comprobar el comportamiento del sistema en una ventana de tiempo mayor. tolerance to salinity ranges, which is why many of them were present both in the estuarine environment and under the marine influence whereas species such as Etrumeus acuminatus, Achirus mazatlanus, Sphoeroiedes lobatus, Oligoplites saurus, Bairdiella sp., Diplectrum sp., Engraulis ringens, and Opisthonema sp., which mostly belong to the marine component such as Etrumeus acuminatus, Engraulis ringens and Opisthonema sp., remained in one zone or area. Specifically, in the external zone they were positively associated with the highest transparency, reflecting the preference of these species for specific physicochemical characteristics.

Therefore, it is possible to hypothesize that in an estuarine environment, the temporal variation of environmental conditions would be modulating the distribution, abundance, and, in general, the community of fish larvae. Likewise, these seasonal and temporal fluctuations represent the reproductive strategies of each species linked to their habitat (Sánchez, 1997), assuming the availability of food for their survival (Whitehead et al., 1988), since frequently the abundance of fish larvae is closely related to the biomass of zooplankton (KaundaArara et al., 2009).

According to the results obtained, the Gulf of Guayaquil, at least during the sampled period, presents an assembly of fish larvae with a taxonomic composition composed mainly of the presence of estuarine species with the dominance of a family (Engraulidae). This dominance could be the result of the effect of various physicalchemical factors, among which salinity, transparency and the reproductive events of the species present in the area stood out, what allows to infer that in general this section of the gulf (external area) is an important area as a nursery for species. It would be interesting to carry out more studies and with longer samplings to check the behavior of the system in a longer window of time.

\section{ACKNOWLEDGEMENTS}

To the oceanographer Mario Hurtado for preparing the maps of this manuscript. To the SENESCYT (National Secretariat for Higher Education, Science, Technology and Innovation) of Ecuador, the entity that financed this project within the first nautical mile off the Ecuadorian coast of the province of Guayas during June to December 2012. The project was executed by the National Fisheries Institute through the specific agreement 20120132. 


\section{AGRADECIMIENTOS}

Al oceanógrafo Mario Hurtado por la elaboración de los mapas de este manuscrito. A la Senescyt (Secretaría Nacional de Educación Superior, Ciencia, Tecnología e Innovación) de Ecuador, ente que financió este proyecto dentro de la primera milla náutica frente a la costa ecuatoriana de la provincia de Guayas durante junio a diciembre de 2012. Proyecto ejecutado por el Instituto Nacional de Pesca a través del convenio específico 20120132.

\section{BIBLIOGRAFÍA/LITERATURE CITED}

Able, K., J. Manderson and A. Studholme. 1999. Habitat quality for shallow water fishes in an urban estuary: the effects of man-made structures on growth. Mar. Ecol. Prog. Ser., 187: 227-235.

Arias de la Peña, C.M. 1991. Preliminary study of some groups of the ichthyoplankton of the Gulf of Nicoya. Costa Rica. Master's Thesis. Univ. Costa Rica. Ayón, H. 1987. Main geomorphological features of the Ecuadorian coast. Guayaquil. 10 p.

Barletta, M. and A. Barletta-Bergan. 2009. Endogenous activity rhythms of larval fish assemblages in a mangrove-fringed estuary in North Brazil. Open. Fish. Sci. J., 2: 15-24.

Barletta, M., A. Barletta-Bergan and U. Saint-Paul. 1998. The description of the fishery structure in the mangrove dominated region of Braganga (State of Pará-North Brazil). Ekotropical, 4: 41-53.

Barletta-Bergan, A., M. Barletta and U. Saint-Paul. 2002. Structure and seasonal dynamics of larval fish in the Caeté River in northern Brazil. Est. Coast. Shelf Sci., 154: 193-206.

Beck, M., K. Heck, K. Able, D. Childers, D. Eggleston, B. Gillanders, B. Halpern, C. Hays, K. Hostino, T. Minello, R. Orth, P. Sheridanand and M. Weinstein. 2001. The role of nearshore ecosystems as fish and shellfish nurseries. Bioscience, 51: 633-641.

Beltrán-León, B. and R. Ríos. 2000. Early stages of fish in the Colombian Pacific. Vol. 1. National Institute of Fisheries and Aquaculture. Buenaventura. $359 \mathrm{p}$.

Beltrán-León, B. and R. Ríos. 2001. Early stages of fish of the Colombian Pacific. Volume 2. National Institute of Fisheries and Aquaculture. Buenaventura. $360-727 \mathrm{p}$.

Boyer, J., J. Fourqrean and R. Jones. 1997. Spatial characterization of water quality in Florida Bay and Whitewater Bay by multivariate analyzes: Zones of similar influence. Estuaries, 20: 743-758.

CAAM (Environmental Advisory Commission). 1995. Development and environmental problems of the Gulf of Guayaquil area. Create Image, Quito.

Calderón, G. 2011. Catalog of fish eggs and larvae collected in Ecuadorian waters. Special Bull., 2(4): 118.

Calderón, G., G. Ayora and E. Elías. 2018. Distribution and abundance of ichthyoplankton within the first nautical mile off the province of Santa Elena Ecuador. Rev. Cienc. Mar Limnol., 12(1): 10.

Cajas, L. and D. Hinostroza. 1981. Clupeid and engraulid eggs and larvae in the Gulf of Guayaquil. Rev. Cienc. Mar. Limnol., 2: 37-47.

Cowan Jr, J.H. and R.F. Shaw. 2002. Recruitment: 88-111. In: Fuiman L.A. and R.G. Werner (Eds.). Fish. Sci.: the unique contributions of the early stages. Blackwell Science. $326 \mathrm{p}$.

Cucalón, E. 1996. First part: Oceanography and physical systems. In Biophysical Systems of the Gulf of Guayaquil (1st ed.: 1-109). Quito: Environmental Advisory Commission of the Presidency of the Republic of Ecuador.

Day, J.W, C.A.S. Hall, W.M. Kemp and A. Yañez-Arancibia (Eds). Estuarine Ecology. John Wiley \& Sons, Inc., New York, 558 p.

Favero, M. and C.A. Lasta. 2001. Fish breeding area of the Samborombón Bay (Argentina) as sustenance for migratory fish-eating birds: trophic interactions. Final report. Torch Foundation. Project A-13672/1-4: 44.

García, M.L. 1983. Variability in the distribution and abundance of mackerel eggs and larvae (Scomber japonicus peruanus) and some clupeids in Ecuadorian waters. FAO Fish. Rep., 291(2): 553.

Hammer, O., D. Harper and P. Ryan. 2001. Paleontological statistics software: package for education and data analysis. Palaeontol. Electron., 4: 1-9. 
Holliday, F.G.T. 1971: Salinity: Animals-Fishes: 997-1033. In: Kinne, O. (Ed.). Marine Ecology Vol. 1. Part. 2. Wiley-Interscien, London.

Jiménez, I.L. 2008. Prospecting ichthyoplankton on the surface of the Colombian Pacific Ocean. Period 19.sep-08.oct.04.regional study of the El Niño phenomenon (ERFEN). Thesis. Univ. Militar Nueva Granada.

Jiménez, R and D. Bonilla. 1980. Composition and distribution of plankton biomass on the equatorial front. Inocate Ecuador Oceanogr. Act. Pac., 1(1): 19-64.

Kaunda-Arara, B., J.M. Mwaluma, G.A. Locham, V. Oresland and M.K. Osore. 2009. Temporal variability in fish larval supply to Malindi Marine Park, coastal Kenya. Aquat. Conserv. Mar. Freshw. Ecosyst., 19(S1): S10-S18.

Ketchum, B.H. 1992. Ecosystems of the World. Est. Encl. Be., 183-203.

Krebs, C. 1999. Ecological methodology. Benjamin Cumming. California. 760 p.

Laroche, J., E. Baran and N.B. Rasoanandrasana. 1997. Temporal patterns in a fish assemblage of a semiarid mangrove zone in Madagascar. J. Fish Biol., 51: $3-20$.

Luzuriaga de Cruz, M., D. Ortega and E. Elías. 1998. Abundance and distribution of ichthyoplankton, phytoplankton, and zooplankton in the Ecuadorian Sea in April 1995. Act. Oceanogr. Esp., 9(1).

Maes, J., A. Taillieu., P.A. Van Damme, K. Cottenie and F. Ollevier. 1998. Seasonal patterns in the fish and crustacean community of a turbid temperate estuary (Zeeschelde Estuary. Belgium). Est. Coast. Shelf Sci., 47: 143-151.

McCune, B. and J.B. Grace. 2002. Analysis of ecological communities. Bruce McCune, US. 143-164.

McLuski, D. and E. Marriot. 2011. Challenging paradigms in estuarine ecology and management. Est. Coast. Shelf Sci., 94.

Meadow, M. and R. Buchelli. 2012. Distribution and abundance of plankton in the Daule-Peripa reservoir during 2011-2012. Bol. Cient. Tecn., 14(2).

Montaño-Armijos, M. and T. Sanfeliu-Montolio. 2008. Guayas ecosystems (Ecuador). Environ. Sust. Rev. Tecn. ESPOL., 21(1): 1-6.

Morais, T. 1994. The abundance and diversity of larval and juvenile fish in a tropical estuary. Est. Coast. Shelf Sci., 17: $216-225$.

Moser, H.G. 1996. The early stages of fishes in the California Current region. CalCOFI. Atlas No. 33. 1505 p.

Moser, H.G. and P.E. Smith. 1993. Larval fish assemblages and oceanic boundaries. Bull. Mar. Sci., 53(2): 283-289.

Neira, F. and I. Potter. 1992. Movement of larval fishes through the entrance channel of a seasonally open estuary in Western Australia. Est. Coast. Shelf Sci., 35: 213-224.

Ocaña-Luna, A. and M. Sánchez-Ramírez. 2003. Diversity of Ichthyoplankton in Tampamachoco Lagoon. Veracruz. Mexico. An. Inst. Biol., 74(2): 179-193.

Ortega, D., E. Elías and R Zurita. 1996. Distribution of ichthyoplankton and zooplankton on the Ecuadorian coast in September 1995. Bol. Cient. Tec., 14(1): 52-64.

Ottersen, G., S. Kim, G. Huse, J. J. Polovina and N.C. Stenseth. 2010. Major pathways by which climate may force marine fish populations. J. Mar. Syst., (3): 343-360.

Pérez-Ruzafa, A., M.C. Mompean and C. Marcos. 2007. Hydrographic, geomorphologic and fish assemblage relationships in coastal lagoons. Hydrobiologia, 107-125.

Peribonio, R., R. Repelín, M. Luzuriaga, D. Hinostroza and M.E. Villarroel. 1981. Ecological study of the mesoplankton of the Gulf of Guayaquil abundance. nictemeral cycles and relationships between the Guayas river estuary and the ocean. Bol. Cient. Tecn., 4(2).

Pittman, S.C., A. McAlpine and K. Pittman. 2004. Linking fish and prawns to their environment: a hierarchical landscape approach. Mar. Ecol. Prog Ser., 283: $233-254$

Prado, M., L. Troccoli and E. Moncayo. 2015. Structural changes of microfitoplankton in the coastal zone of the El Oro-Ecuador province in the dry season. Bol. Inst. Oceanogr. Venez., 542: 139-152.

Ramos, S., R. Cowen and A. Bordalo. 2005. Temporal and spatial distributions of larval fish assemblages in the Lima estuary (Portugal). Est. Coast. Shelf Sci., 66: 303-314.

Richards, W.J. and K.C. Lindeman. 1987. Recruitment dynamics of reef fishes' planktonic processes settlement and demersal ecologies and fishery analysis. Bull. Mar. Sci., (41): 392-410.

Richards, W. 2005. Early stages of Atlantic fishes: an identification guide for the Western Central North Atlantic. Vol. 1. Taylor and Francis Group. CRC Press. Boca Raton. USES. 2640 p.

Saborido, F. 2008. Ecology of reproduction and reproductive potential in marine fish populations. Inst. Invest. Mar. Univ. Vigo. 71 p. 
Salcedo, J. and D. Coello. 2018. Plankton dynamics in the first nautical mile off the province of El Oro. Ecuador. Rev. Biol. Trop., 66(2): 836-847.

Sánchez-Ramírez, G. 1997. Abundance, growth and mortality of Chloroscombrus chysurus (Pisces Carangidae) larvae in the southern Gulf of Mexico. Doctoral thesis. Univ. Nac. Aut. México. 85 p.

Shannon, C.E. and W. Weaver. 1963. The mathematical theory of communication. Urban. Univ. Illinois Press, $117 \mathrm{p}$.

Silva-Segundo, C.A, R. Funes-Rodríguez, M.E. Hernández-Rivas, E. Ríos-Jara, E.G. Robles-Jarero and A. Hinojosa-Medina. 2008. Associations of fish larvae in relation to environmental changes in the Bays of Chamela, Jalisco and Santiago, Manzanillo, Colima (2001-2002). Hydrobiologia, 18(1): 89-103.

Smith, E. and S. Richardson. 1979. Model techniques for prospecting eggs and larvae of pelagic fish. FAO. Doc. Tec. Pesca, (175): 1-107.

Sheskin, D. 2004. Parametric and nonparametric statistical procedures. Chapman and Hall. Boca Raton. US. 423 p.

Stevenson, M. 1981. Seasonal variations in the Gulf of Guayaquil, a tropical estuary. Bol. Cient. Tecn., 4(1): 5-28.

Tsirtsis, G. and M. Karydis. 1998. Evaluation of phytoplankton community indices for detecting eutrophic trends in the marine environment. Environ. Monit. Assess., 50: 255-269.

Torres, G., V. Calderón, E. Franco, T. Cedeño and E. Salazar. 2003-2004. Composition of plankton in the Puntilla de Santa Elena during August 2002. Act. Oceanogr. Pac., 12(1): 63-74.

Twilley, R., W. Cárdenas, V. Rivera-Monroy, J. Espinoza, R. Suescum, M. Armijos and L. Solórzano. 2001. The Gulf of Guayaquil and the Guayas river estuary. Ecuador: 245-263. Coast. Mar. Ecosyst. of Latin America.

Whitehead, P.J.P., G.J. Nelson and T. Wongratana. 1988. FAO species catalog. Clupeoid fishes of the world (Suborder Clupeoidei). An annotated and illustrated catalog of the herrings, sardines, pilchards, sprats, anchovies, and wolf-herrings. Part 2. Engraulidae. FAO Fish. Syn., 125(17): $305-579$.

Whitehead, P.J.P. and R. Rodríguez-Sánchez. 1995. Engraulidae. In: Fischer W. F Krupp, W. Schneider, C. Sommer, K.E. Carpenter and V.H. Niem (Eds). FAO Guide to Species Identification for Fishing Purposes. Central-Eastern Pacific. Vol. II and III Parts 1 and 2: 1067-1068.

Whitfield, A. 1989. Fish larval composition abundance and seasonality in a Southern-African estuarine lake. S.A. J. Zool., 24: $217-224$.

Whitfield, A. 1999. Ichthyofaunal assemblages in estuaries: A South African case study. Rev. Fish Biol. Fish., 9: 151-186.

Yáñez-Arancibia, A. and R. Nugent. 1977. The ecological role of fish in estuaries and coastal lagoons. An. Centro Cien. Mar Limnol. Univ. Nac. Auton. Mexico. 4: 107-117.

Yáñez-Arancibia, A., A.L. Lara-Domínguez, A. Aguirre-León, S. Díaz-Ruiz, F. Amezcua-Linares, D. Flores-Hernández and P. Chavance. 1985. Ecology of dominant fish populations in tropical estuaries: environmental factors that regulate biological strategies and production: 311-366. In: Yáñez-Arancibia, A. (Ed.). Fish community ecology in estuaries and coastal lagoons: Towards ecosystem integration. Univ. Nac. Aut. México.

RECIBIDO/RECEIVED: 16/08/2019

APROBADO/APPROVED: 03/05/2020 